Prepared in cooperation with the Tompkins County Department of Planning

\title{
Hydrogeology and Water Quality of the Stratified-Drift Aquifer in the Pony Hollow Creek Valley, Tompkins County, New York
}

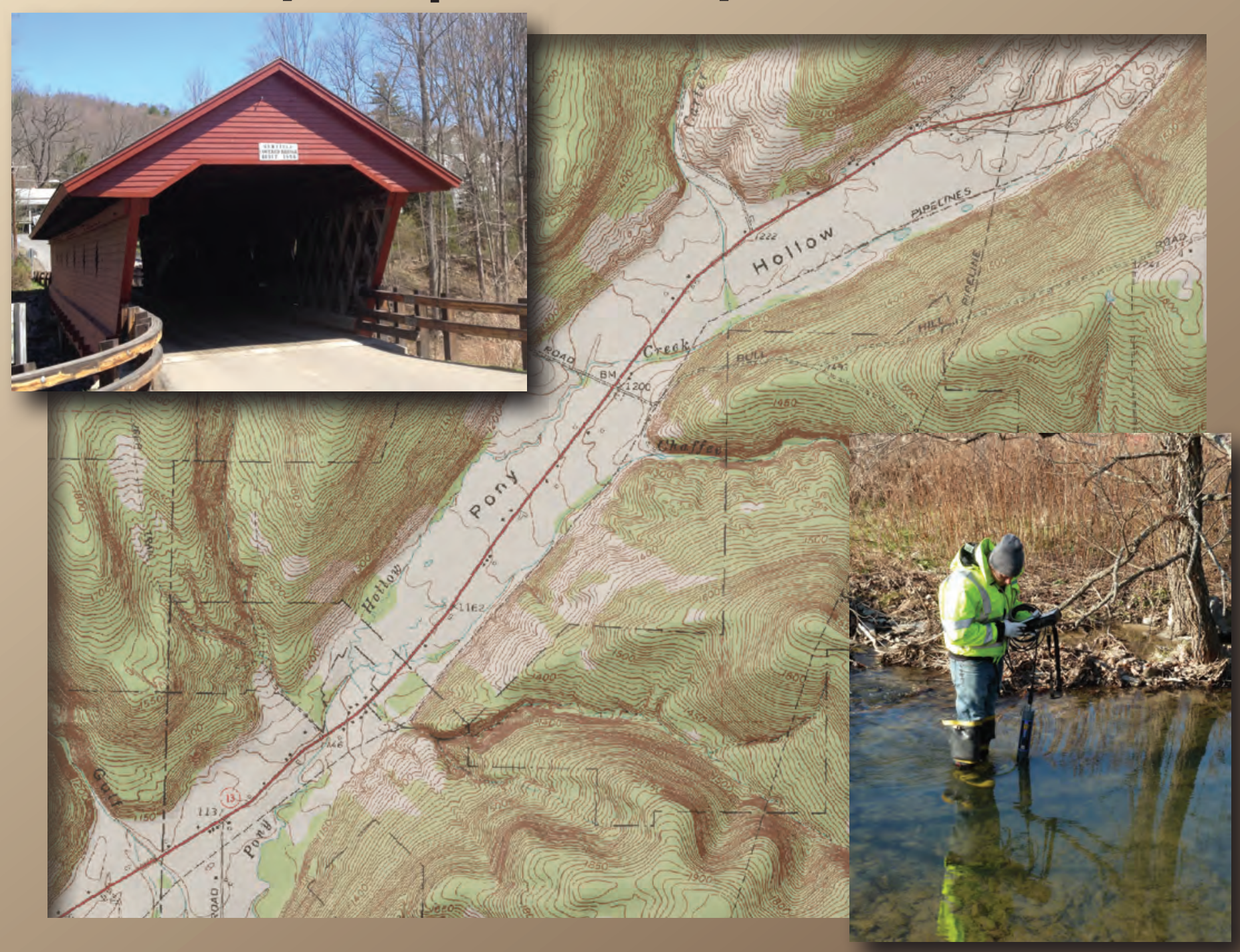

Scientific Investigations Report 2014-5059

U.S. Department of the Interior

U.S. Geological Survey 
Cover. 1. Newfield Bridge is a wooden covered bridge over Cayuga Creek. It is in Newfield in Tompkins County, New York. It is one of 29 covered bridges in New York State. It was added to the National Register of Historic Places in 2000.

2. Brett Hayhurst, USGS, Ithaca N.Y., taking water-quality samples in Pony Hollow Creek, northeast of Cayuta, on December 13, 2011. 


\section{Hydrogeology and Water Quality of the Stratified-Drift Aquifer in the Pony Hollow Creek Valley, Tompkins County, New York}

By Edward F. Bugliosi, Todd S. Miller, and Richard J. Reynolds

Prepared in cooperation with the Tompkins County Department of Planning

Scientific Investsigations Report 2014-5059 


\title{
U.S. Department of the Interior SALLY JEWELL, Secretary
}

\section{U.S. Geological Survey Suzette M. Kimball, Acting Director}

\author{
U.S. Geological Survey, Reston, Virginia: 2014
}

For more information on the USGS - the Federal source for science about the Earth, its natural and living resources, natural hazards, and the environment, visit http://www.usgs.gov or call 1-888-ASK-USGS.

For an overview of USGS information products, including maps, imagery, and publications, visit http://www.usgs.gov/pubprod

To order this and other USGS information products, visit http://store.usgs.gov

Any use of trade, firm, or product names is for descriptive purposes only and does not imply endorsement by the U.S. Government.

Although this information product, for the most part, is in the public domain, it also may contain copyrighted materials as noted in the text. Permission to reproduce copyrighted items must be secured from the copyright owner.

Suggested citation:

Bugliosi, E.F., Miller, T.S., and Reynolds, R.J., 2014, Hydrogeology and water quality of the stratified-drift aquifer in the Pony Hollow Creek Valley, Tompkins County, New York: U.S. Geological Survey Scientific Investigations Report 2014-5059, 23 p., http://dx.doi.org/10.3133/sir20145059.

ISSN 2328-0328 (online) 


\section{Contents}

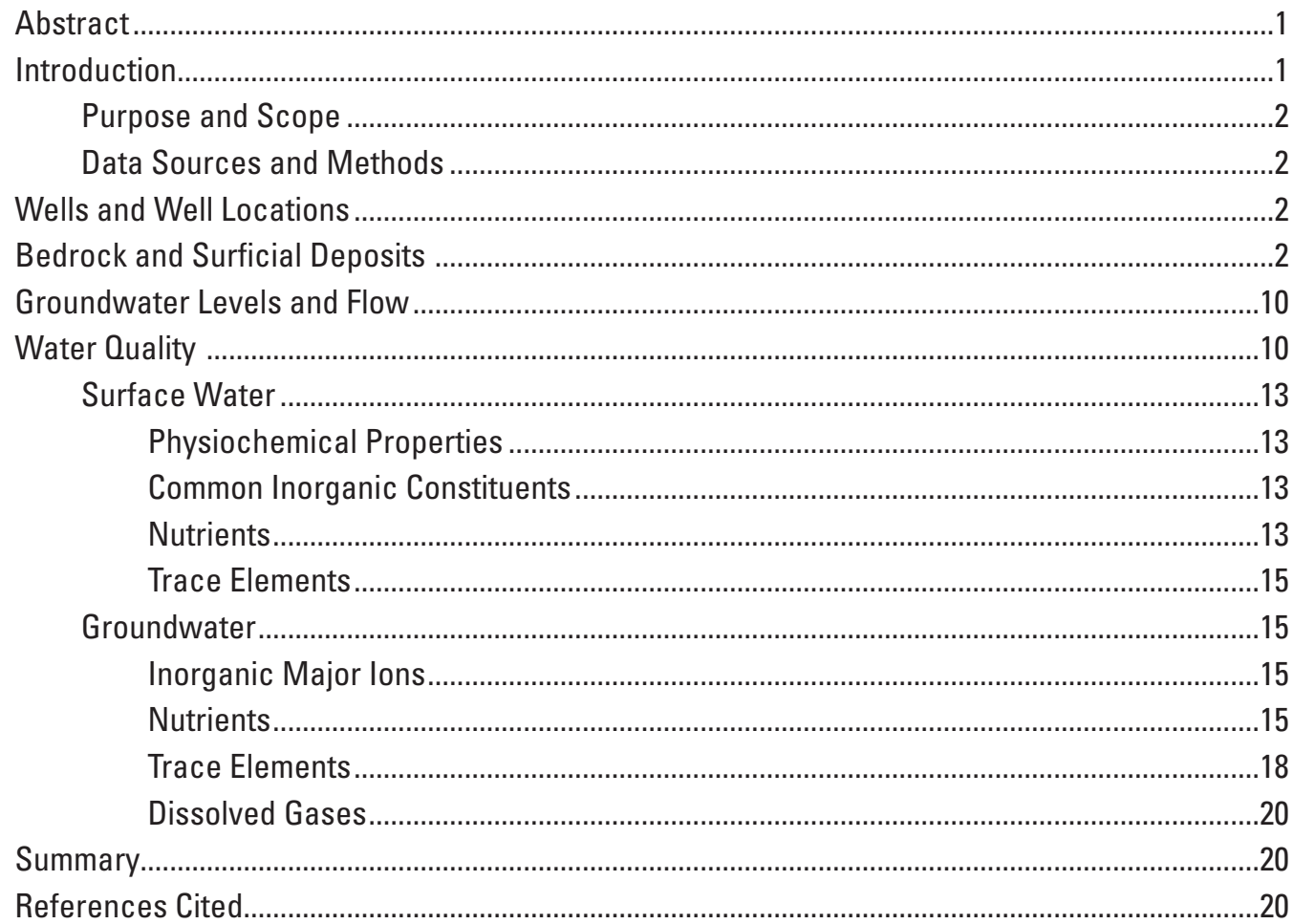

Appendix 1. Records of selected wells in Pony Hollow Creek valley, Tompkins County, New York

\section{Figures}

1. Map showing locations of 17 unconsolidated-aquifer reaches in Tompkins County, New York

2. Map showing physiographic regions of New York and location of the Pony Hollow Creek valley stratified-drift aquifer study area, New York

3. Map showing well and seismic-survey locations and geologic-section locations in the Pony Hollow Creek valley stratified-drift aquifer, Tompkins County, New York...........5

4. Map showing location of Pony Hollow Creek valley stratified-drift aquifer and major lineaments that are faults or suspected faults in Tompkins County, New York .................6

5. Map showing bedrock and surficial deposits in the Pony Hollow Creek valley stratified-drift aquifer, Tompkins County, New York.

6. Diagram showing $A$. Geohydrologic section $A-A^{\prime}$ across the Pony Hollow Creek valley along Connecticut Hill Road; and B. section B-B' across Pony Hollow Creek valley, along Cayuta Road Tompkins County, New York

7. Water-level measurements and water-table surface contours in the Pony Hollow Creek valley Tompkins County, New York.

8. Location of stream sites and wells sampled in the Pony Hollow Creek valley, Tompkins County, New York, December 13-15, 2011 


\section{Tables}

1. Physical properties and concentrations of inorganic constituents, nutrients, and dissolved gases in surface-water samples in the Pony Hollow Creek valley, Tompkins County, New York, December 13, 2011.

2. Concentrations of trace metals in surface-water samples from the Pony Hollow Creek valley, Tompkins County, New York, December 13, 2011.

3. Physical properties and concentrations of inorganic constituents, nutrients, and dissolved gases in groundwater samples from unconsolidated aquifers in the Pony Hollow Creek valley, Tompkins County, New York, December 14-15, 2011

4. Concentrations of trace metals in groundwater samples from the Pony Hollow Creek valley, Tompkins County, New York, December 14-15, 2011

\section{Conversion Factors and Datum}

\begin{tabular}{lcl}
\hline Multiply & \multicolumn{1}{c}{ By } & To obtain \\
\hline & Length & \\
\hline inch (in.) & 2.54 & centimeter $(\mathrm{cm})$ \\
inch (in.) & 25.4 & millimeter $(\mathrm{mm})$ \\
foot (ft) & 0.3048 & meter $(\mathrm{m})$ \\
mile (mi) & 1.609 & kilometer $(\mathrm{km})$ \\
\hline & Volume & \\
\hline gallon (gal) & 3.785 & liter $(\mathrm{L})$ \\
cubic foot $\left(\mathrm{ft}^{3}\right)$ & 0.02832 & cubic meter $\left(\mathrm{m}^{3}\right)$ \\
\hline & Flow rate & \\
\hline gallon per minute $(\mathrm{gal} / \mathrm{min})$ & 0.06309 & liter per second $(\mathrm{L} / \mathrm{s})$ \\
cubic foot per second $\left(\mathrm{ft}^{3} / \mathrm{s}\right)$ & 0.02832 & cubic meter per second $\left(\mathrm{m}^{3} / \mathrm{s}\right)$ \\
\hline
\end{tabular}

Temperature in degrees Celsius $\left({ }^{\circ} \mathrm{C}\right)$ may be converted to degrees Fahrenheit $\left({ }^{\circ} \mathrm{F}\right)$ as follows:

$$
{ }^{\circ} \mathrm{F}=\left(1.8 x^{\circ} \mathrm{C}\right)+32
$$

Temperature in degrees Fahrenheit $\left({ }^{\circ} \mathrm{F}\right)$ may be converted to degrees Celsius $\left({ }^{\circ} \mathrm{C}\right)$ as follows:

$$
{ }^{\circ} \mathrm{C}=\left({ }^{\circ} \mathrm{F}-32\right) / 1.8
$$

Vertical coordinate information is referenced to the North American Vertical Datum of 1988 (NAVD 88).

Horizontal coordinate information is referenced to the North American Datum of 1983 (NAD 83).

Altitude, as used in this report, refers to distance above the vertical datum.

Specific conductance is given in microsiemens per centimeter at 25 degrees Celsius ( $\mu \mathrm{S} / \mathrm{cm}$ at $\left.25^{\circ} \mathrm{C}\right)$.

Concentrations of chemical constituents in water are given either in milligrams per liter (mg/L) or micrograms per liter ( $\mu \mathrm{g} / \mathrm{L})$. 


\section{Abbreviations}

$\begin{array}{ll}\text { EPA } & \text { U.S. Environmental Protection Agency } \\ \text { HA } & \text { health advisory } \\ \text { H/V } & \text { horizontal-to-vertical } \\ \text { MCL } & \text { maximum contaminant level } \\ \text { NWIS } & \text { National Water Information System } \\ \text { NWQL } & \text { National Water Quality Laboratory } \\ \text { NYSDEC } & \text { New York State Department of Environmental Conservation } \\ \text { SMCL } & \text { secondary maximum contaminant level } \\ \text { USGS } & \text { U.S. Geological Survey }\end{array}$





\title{
Hydrogeology and Water Quality of the Stratified-Drift Aquifer in the Pony Hollow Creek Valley, Tompkins County, New York
}

\author{
By E. F. Bugliosi, Todd S. Miller, and Richard Reynolds
}

\section{Abstract}

The lithology, areal extent, and the water-table configuration in stratified-drift aquifers in the northern part of the Pony Hollow Creek valley in the Town of Newfield, New York, were mapped as part of an ongoing aquifer mapping program in Tompkins County. Surficial geologic and soil maps, well and test-boring records, light detection and ranging (lidar) data, water-level measurements, and passive-seismic surveys were used to map the aquifer geometry, construct geologic sections, and determine the depth to bedrock at selected locations throughout the valley. Additionally, waterquality samples were collected from selected streams and wells to characterize the quality of surface and groundwater in the study area.

Sedimentary bedrock underlies the study area and is overlain by unstratified drift (till), stratified drift (glaciolacustrine and glaciofluvial deposits), and recent post glacial alluvium. The major type of unconsolidated, wateryielding material in the study area is stratified drift, which consists of glaciofluvial sand and gravel, and is present in sufficient amounts in most places to form an extensive unconfined aquifer throughout the study area, which is the source of water for most residents, farms, and businesses in the valleys.

A map of the water table in the unconfined aquifer was constructed by using (1) measurements made between the mid-1960s through 2010, (2) control on the altitudes of perennial streams at 10-foot contour intervals from lidar data collected by Tompkins County, and (3) water surfaces of ponds and wetlands that are hydraulically connected to the unconfined aquifer. Water-table contours indicate that the direction of groundwater flow within the stratified-drift aquifer is predominantly from the valley walls toward the streams and ponds in the central part of the valley where groundwater then flows southwestward (down valley) toward the confluence with the Cayuta Creek valley. Locally, the direction of groundwater flow is radially away from groundwater mounds that have formed beneath upland tributaries that lose water where they flow on alluvial fans on the margins of the valley.
In some places, groundwater that would normally flow toward streams is intercepted by pumping wells.

Surface-water samples were collected in 2001 at four sites including Carter, Pony Hollow (two sites), and Chafee Creeks, and from six wells throughout the aquifer. Calcium dominates the cation composition and bicarbonate dominates the anion composition in groundwater and surface-water samples and none of the common inorganic constituents collected exceeded any Federal or State water-quality standards. Groundwater samples were collected from six wells all completed in the unconfined sand and gravel aquifer. Concentrations of calcium and magnesium dominated the ionic composition of the groundwater in all wells sampled. Nitrate, orthophosphate, and trace metals were detected in all groundwater samples, but none were more than U.S. Environmental Protection Agency or New York State Department of Health regulatory limits.

\section{Introduction}

In 2009, the U.S. Geological Survey (USGS) began an appraisal of the stratified-drift aquifer in the Pony Hollow Creek valley in Tompkins County, New York. This study is a continuation of a series of hydrogeologic appraisals of the stratified-drift aquifers in Tompkins County, done in cooperation with the County and Towns within the county (fig. 1). The hydrogeology for much of the study area was characterized by Miller and Pitman (2012) in a cooperative study with the New York State Department of Environmental Conservation (NYSDEC) of the Cayuta Creek Valley, to which the Pony Hollow Creek valley is tributary. These reports provide a foundation for wellhead protection programs, water-resource management and planning, and groundwater remediation activities in upstate New York. Additionally, State, county, municipal, and other governmental agencies are requesting hydrogeologic information that will help decision makers evaluate the potential effects of gas drilling and hydraulic fracturing operations on aquifers that supply potable water. As the major sources of potable groundwater 
in Tompkins County, stratified-drift aquifers need to be delineated and their basic hydrogeologic characteristics determined.

The Pony Hollow Creek valley, in southwestern Tompkins County, is slightly more than 4-miles (mi)-long, trends northeast-southwest, and is a tributary to the 23-mi-long Cayuta Creek valley to the southwest, within the north-central part of the glaciated Appalachian Plateau in central New York (fig. 2). Pony Hollow Creek initially flows southwest out of wetland areas about $3 \mathrm{mi}$ southwest of Newfield, New York, where a regional, low-relief, surface-water divide separates areas of northward drainage to Lake Ontario and southward drainage to the Susquehanna River Basin (not shown).

The physiography of the Pony Hollow Creek valley is described in detail by Miller and Pitman (2012). The valley is generally surrounded by rounded hills of moderate relief several hundred feet above the valley floor. The Pony Hollow Creek valley is one of many examples of bedrock troughs that extend southward from the Finger Lakes to the northern rim of the Appalachian Plateau (fig. 2). Glacial meltwaters and post-glacial streams deposited large amounts of stratified drift composed of coarse-grained sediments (sand and gravel) in the main valleys, forming extensive aquifers that provide the sole sources of water for most residents, farms, and businesses in the valleys.

\section{Purpose and Scope}

This report summarizes the hydrogeology of the stratified-drift aquifer in the Pony Hollow Creek valley in the southwestern part of Tompkins County, New York. The report includes maps that depict the aquifer extent, locations of wells, and results of horizontal-to-vertical (H/V) ambient-noise seismic surveys, nature of surficial deposits, and water-table configuration. The report also summarizes the quality of surface water and groundwater in the valley sampled from selected streams and wells. A table of well data is included in appendix 1 .

\section{Data Sources and Methods}

Most of the aquifer geometry information and well and hydraulic data are from Miller and Pitman (2012). The Miller and Pitman (2012) report includes a 1:24,000-scale surficial-deposits map, subsurface data including well- and test-drilling records, and results from $\mathrm{H} / \mathrm{V}$ ambient-noise seismic surveys (a geophysical method used to estimate the thickness of sediment over bedrock). Sources of well and test-boring data include previous USGS groundwater studies by Miller and Karig (2010) and Miller and Pitman (2012), the USGS National Water Information System (NWIS), and the NYSDEC Water Well Drillers Registration Program (well records from 2000 to 2010). Well data are in Appendix 1.
Well, test-boring, and seismic data (fig. 3), and surficialdeposits data were used to define and map the extent of the aquifers, determine the aquifer lithology and degree of confinement, depict the stratigraphy in two geohydrologic sections, and determine the depth to bedrock and thickness of unconsolidated valley-fill deposits at selected locations. Most well and test-boring records included groundwater-level measurements that were used along with altitudes of stream channels and ponds determined from light detection and ranging (lidar) data to construct a generalized water-table map of the aquifer (Miller and Pitman, 2012).

\section{Wells and Well Locations}

A total of 18 well and associated test-boring records were compiled for this study (fig. 3 and Appendix 1). The locations of wells from the NYSDEC Water Well Drillers Registration Program were field checked by USGS personnel (Miller and Pitman, 2012). The altitudes of land surface at the wells were determined from lidar data. Water-level measuring points were referenced to the lidar data with an accuracy of 1 foot (ft).

\section{Bedrock and Surficial Deposits}

Bedrock in the study area consists of Upper to Middle Devonian shale that is overlain by unconsolidated deposits including till, glaciolacustrine and glaciofluvial deposits, and recent alluvium (fig. 4) (Rickard and Fisher, 1970). Bedrock crops out at land surface along the flanks of many of the valleys and on hilltops (Miller and Pitman, 2012). The regional dip of the strata is southward at 40 to 60 feet per mile (ft/mi); at subregional scales, however, the strata are warped into shallow open folds with axes trending east to northeast, which result in local variations in dip and, in some places, reversal of dip (Miller and Pitman, 2012).

The Pony Hollow Creek valley follows one of a group of predominant lineaments (linear structural features) that are faults or suspected faults in Tompkins County (fig. 4) (Miller and Pitman, 2012, fig.3), which controlled the development of the Pony Hollow Creek valley. The drainage pattern of tributaries in the Pony Hollow Creek valley is consistent with the underlying regional, orthogonal fracture pattern in this area, and is distinct from the more dendritic drainage pattern of the surrounding hillsides. Faults and fractures are found throughout the study area and bedrock uplands, and in some places locally enhance the secondary permeability of the rock, acting as conduits through which groundwater may flow (Fountain and Jacobi, 2000; Miller and Pitman, 2012).

The study area has undergone several major glaciations during the Pleistocene Epoch, which began 2.6 million years ago and ended about 12,000 years before present (Fullerton, 


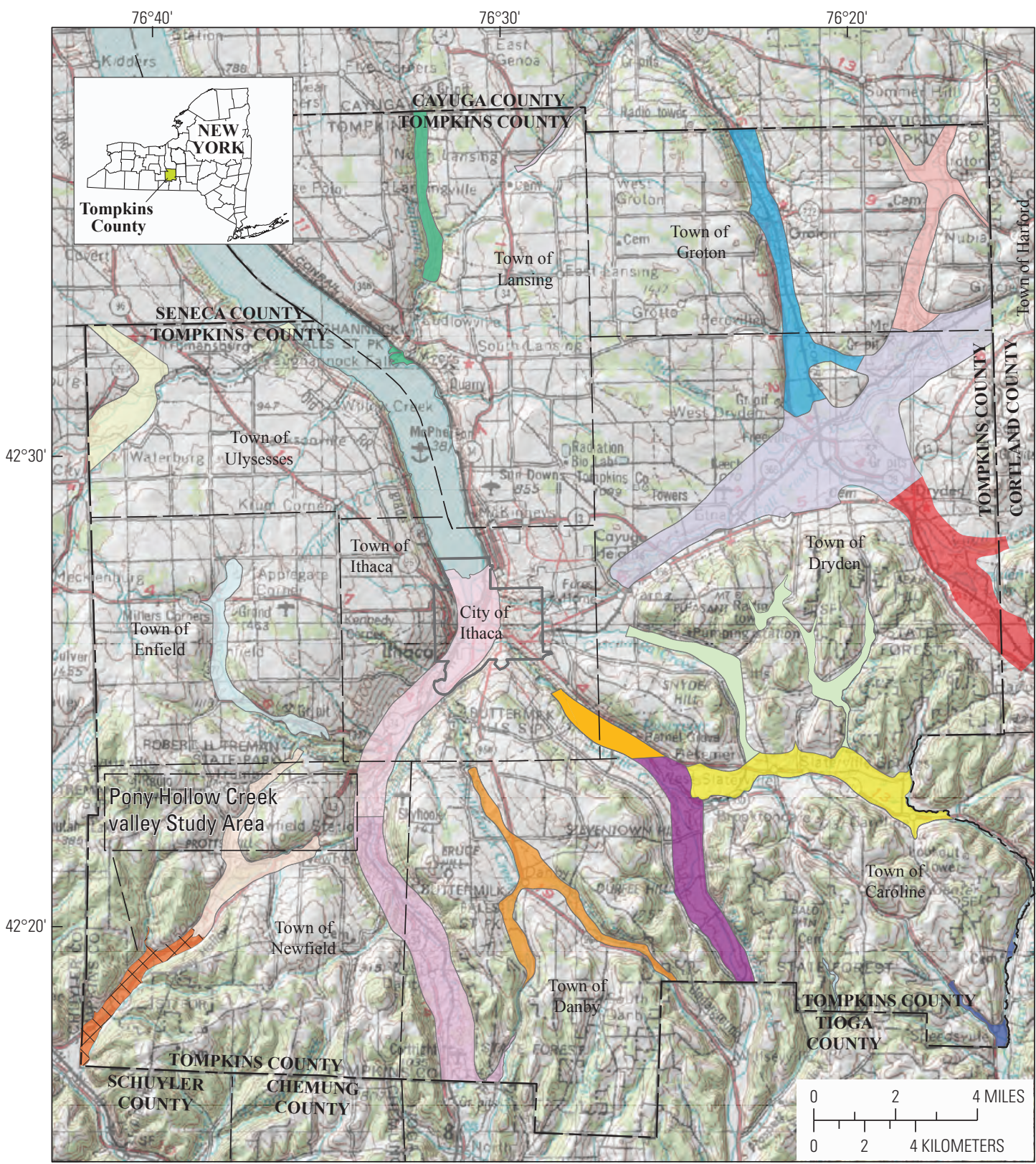

Base from U.S. Geological Survey digital Line graph, scale 1:250,000

Aquifers mapped by T.S. Miller (2000)

EXPLANATION

\section{Aquifer reaches}

Cascadilla Creek valley and upland Sixmile Creek valley

Enfield Creek valley

Lower Cayuga Inlet valley

Lower Fall Creek valley

Lower Sixmile Creek valley (towns of Dryden and Ithaca)

Owasco Inlet valley

Lower Sixmile Creek and Willseyville Creek valleys (town of Caroline)

\section{Aquifer reaches, continued}

Pony Hollow Creek valley (this study)

Salmon Creek/Myers Point/Locke Creek

Taughannock Creek valley and delta

Upper Buttermilk Creek and Danby Creek valleys

Upper Cayuga Inlet valley

Upper Fall Creek valley

Upper Sixmile Creek and West Branch Owego Creek valleys

Virgil Creek, Dryden Lake, and Owego Creek valleys

West Branch Cayuga Inlet and Fish Kill valleys

West Branch Owego Creek valley and tributaries

Figure 1. Locations of 17 unconsolidated-aquifer reaches in Tompkins County, New York. 


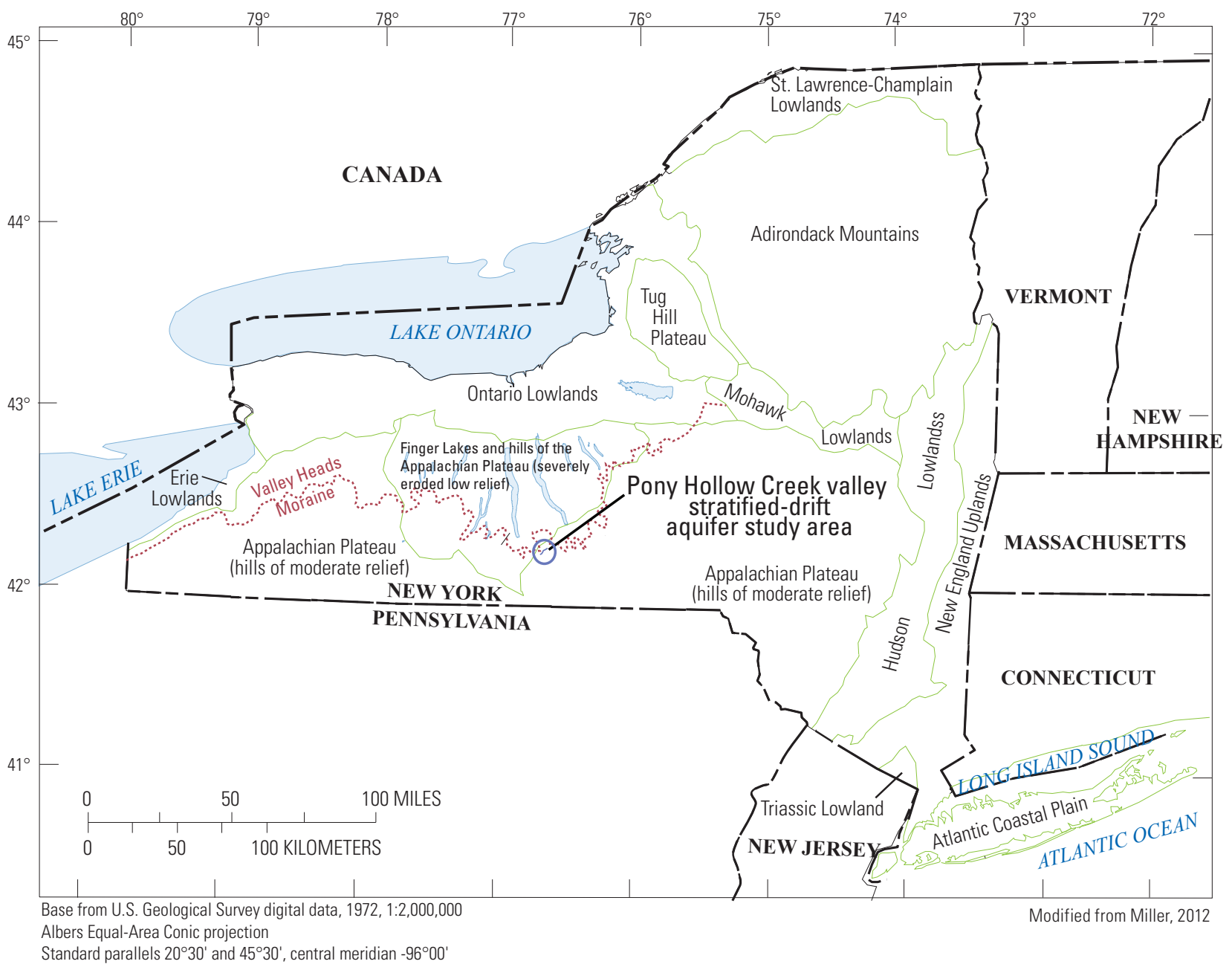

Figure 2. Physiographic regions of New York and location of the Pony Hollow Creek valley stratified-drift aquifer study area, New York.

1980). Most glacial sediments in the Pony Hollow Creek valley were deposited during the end of the most recent (Wisconsin) glacial epoch, from about 20,000 to 11,850 years ago. These sediments are composed mainly of unstratified and stratified glacial drift.

The unstratified glacial drift in the study area consists of till in the uplands that directly overlies bedrock, and is the sole unconsolidated deposit (fig. 5) in the uplands. Till typically has low hydraulic conductivity and therefore, does not form any extensive aquifer in this area (Miller and Pitman, 2012). In contrast, stratified-drift deposits consisting of glaciofluvial, glaciolacustrine, and recent deposits (alluvial sand and gravel, and swamp and marsh sediments) are the major unconsolidated deposits present in the Pony Hollow Creek valley (fig. 5) (Miller and Pitman, 2012). Additionally, fluvial sediments were deposited by glacial meltwaters as the ice retreated and then by post-glacial streams. Glaciofluvial and alluvial deposits form the unconfined aquifer throughout the study area (fig. 4). The geologic framework that forms the aquifer in the Pony Hollow Creek valley is depicted in two geohydrologic sections spanning the valley [(section $A-A^{\prime}$ one-half way down the valley and section $B-B^{\prime}$ towards the southern end of the valley (fig. 6)]. The prevalence of alluvial deposits in many places indicates that post-glacial erosion of the uplands contributed a large volume of sediment that has accumulated in the valleys (Miller and Pitman, 2012). The thickness of the unconsolidated deposits in the Pony Hollow Creek valley ranges from 22-85 ft (based on well depth and casing depth) — the depth to bedrock ranges between $23-100 \mathrm{ft}$ at three wells in the valley (appendix 1).

In the 4-mi-long Pony Hollow Creek valley, outwash, kame, and post-glacial alluvial sediments are the predominant deposits (fig. 5). In the northern part of the valley a kame morainal deposit blends into outwash sand and gravel to the southwest and then into mostly alluvium, southwest to the mouth of the valley and the confluence with the larger Cayuta Creek valley near the border between Schuyler County and Tompkins County where some inwash sand and gravel were locally deposited (fig. 5). The kame end moraine makes a low-relief, major-basin drainage divide crossing the valley 


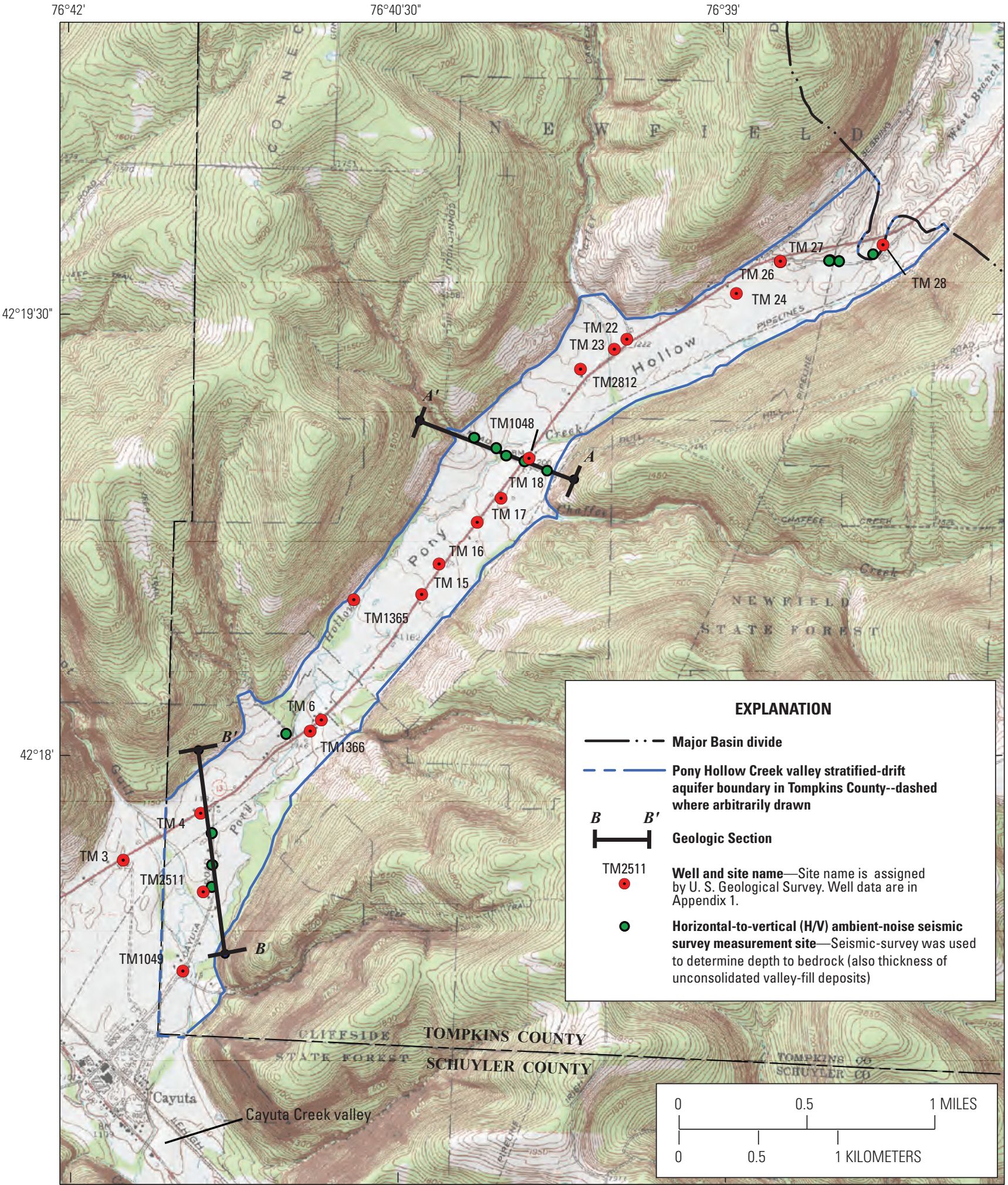

Base from U.S. Geological Survey, Seamless Data Distribution System, accessed in 2009 at http://seamless. usgs.gov, Universal Transverse Mercator (UTM) projection,

Modified from MIller and Pittman, 2012 Zone 18. Shading from 30-meter Digital Elevation Model accessed in 2009 at http://nationalmap.gov/elevation.html\#data, UTM, Zone 18.

Figure 3. Well and seismic-survey locations and geologic-section locations in the Pony Hollow Creek valley stratified-drift aquifer, Tompkins County, New York. 


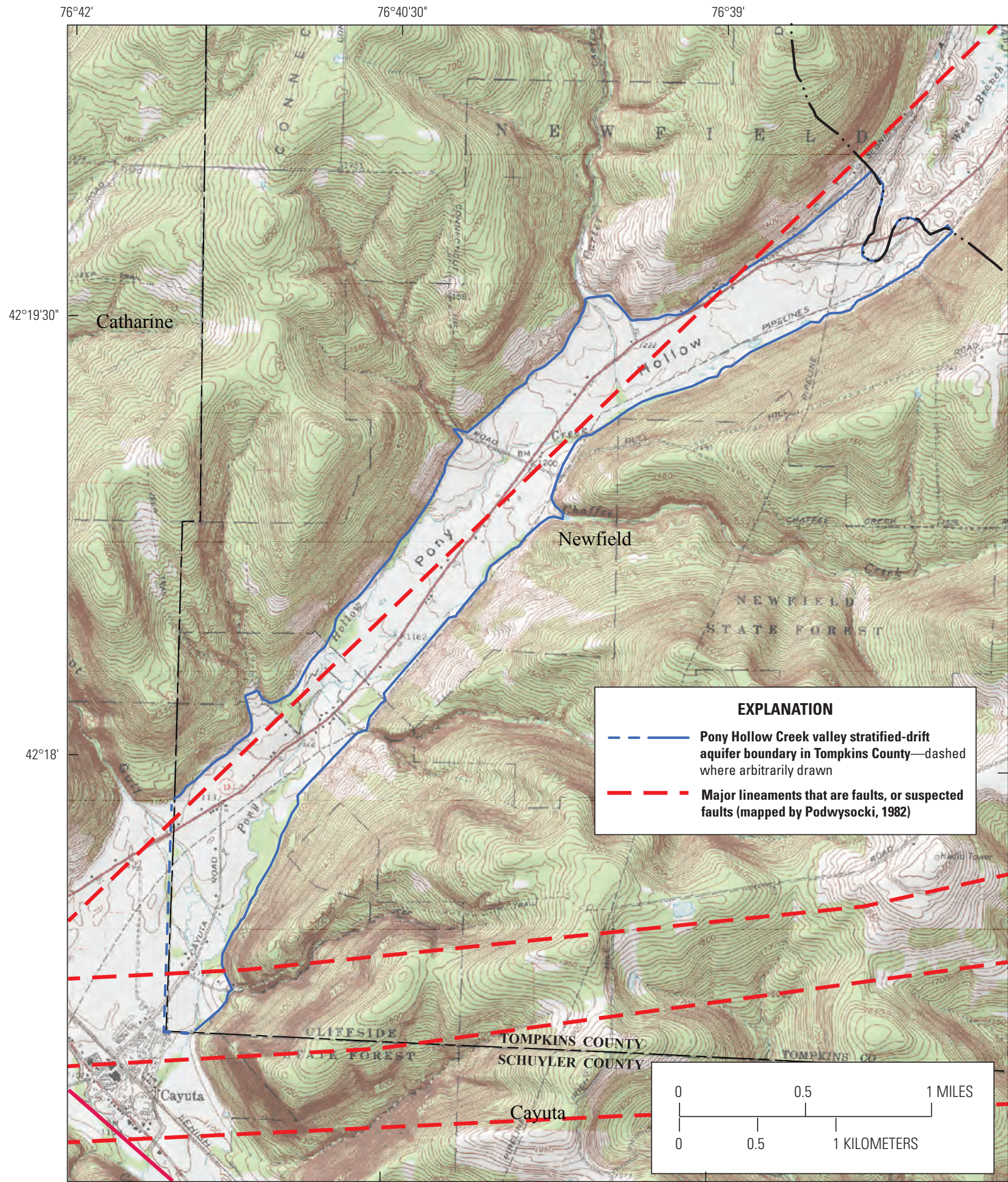

Base from U.S. Geological Survey, Seamless Data Distribution System, accessed in 2009 at http://seamless.usgs.gov, Universal Transverse Mercator (UTM) projection,

(Map modified from Miller and Pitman, 2012; Lineaments Zone 18. Shading from 30-meter Digital Elevation Model accessed in 2009 at

http://nationalmap.gov/elevation.htm|\#data, UTM, Zone 18.

Figure 4. Location of Pony Hollow Creek valley stratified-drift aquifer and major lineaments that are faults or suspected faults in Tompkins County, New York. 


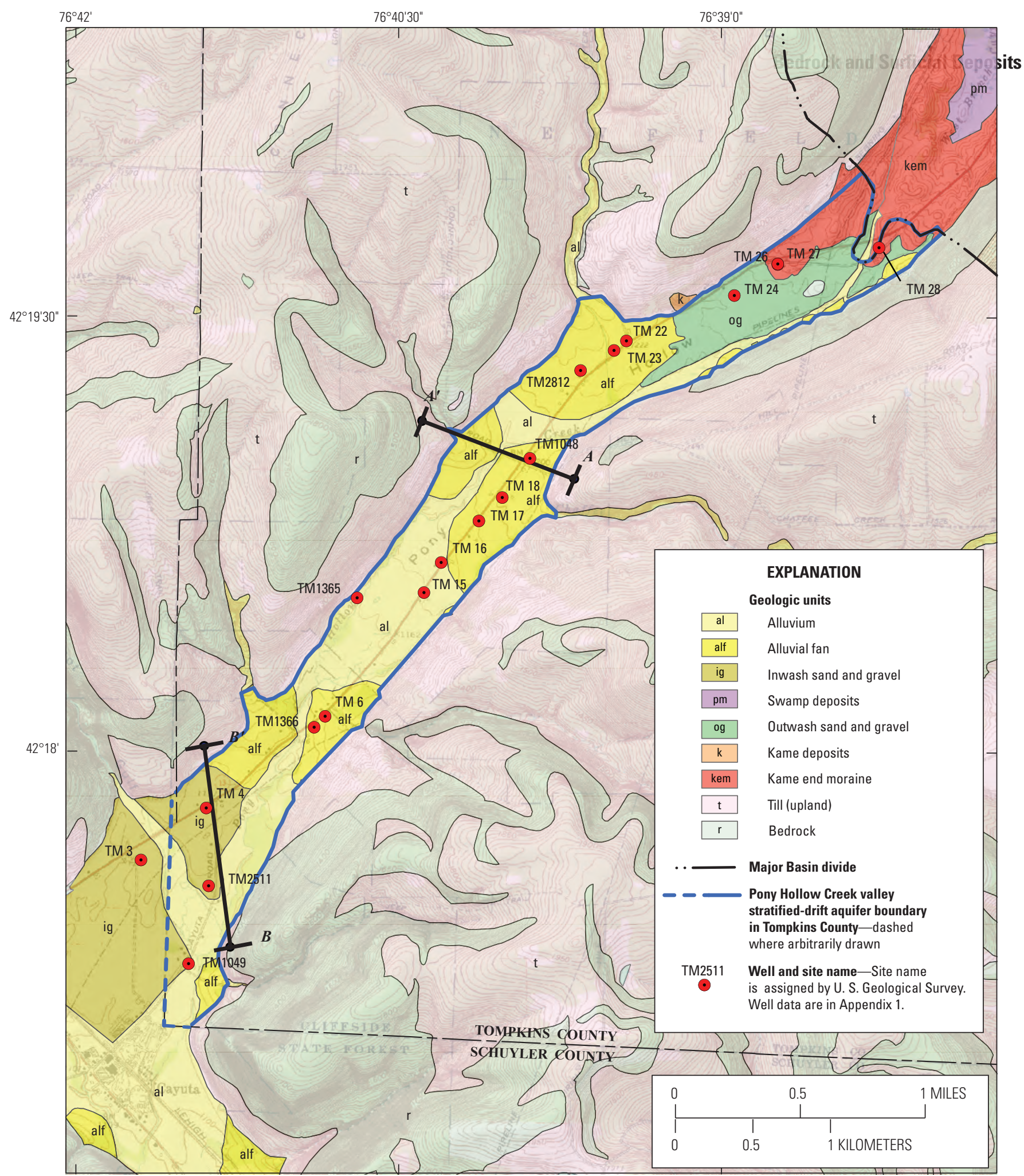

Base from U.S. Geological Survey, Seamless Data Distribution System, accessed in 2009 at http://seamless.usgs.gov, Universal Transverse Mercator (UTM) projection,

Zone 18. Shading from 30-meter Digital Elevation Model accessed in 2009 at

http://nationalmap.gov/elevation.html\#data, UTM, Zone 18.

Figure 5. Bedrock and surficial deposits in the Pony Hollow Creek valley stratified-drift aquifer, Tompkins County, New York. 

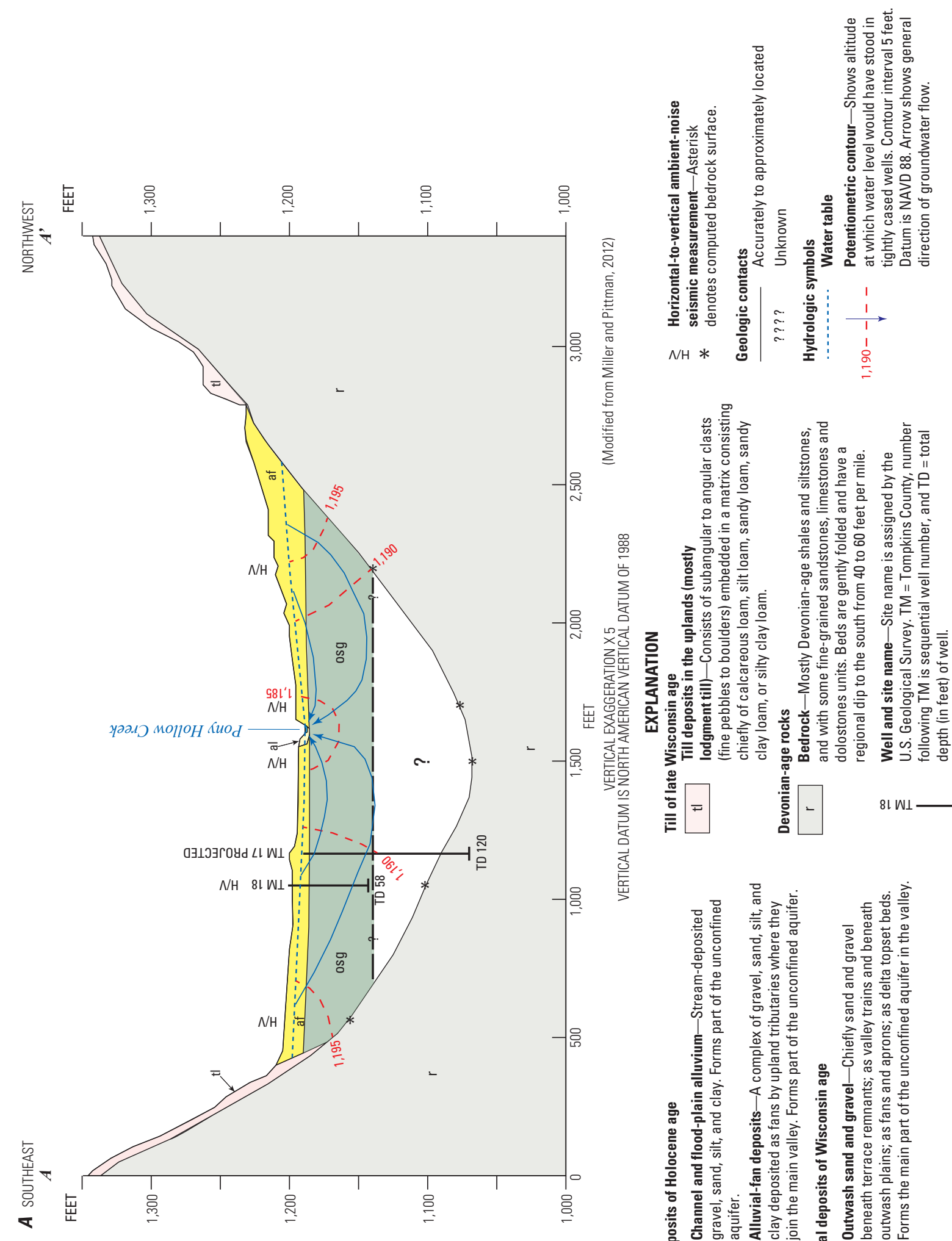

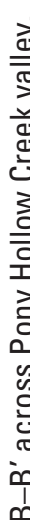

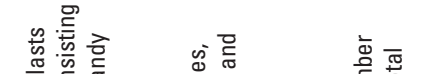

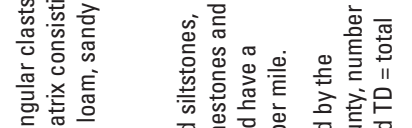

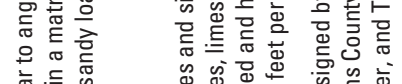

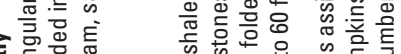

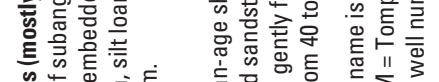

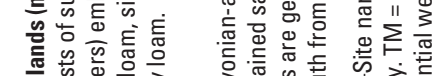

2 흘.

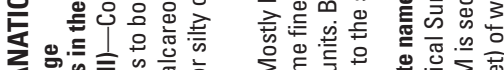

㲾.

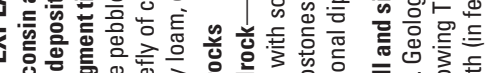

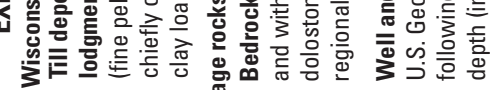

产

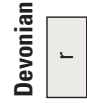

$8 \mathrm{LL} \longrightarrow$

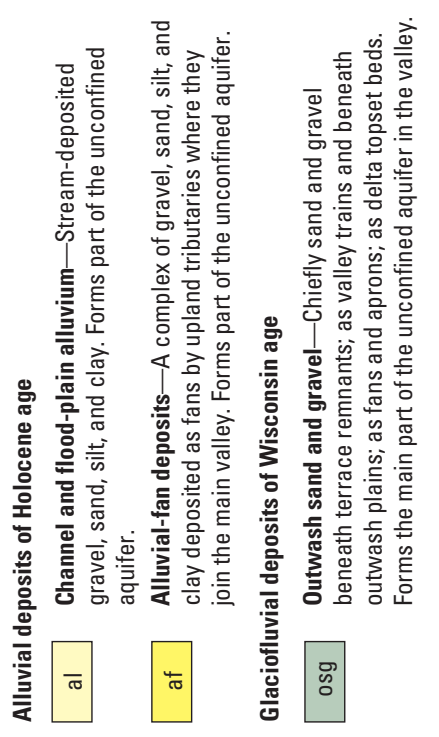

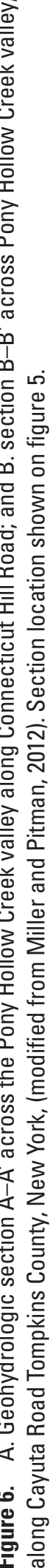



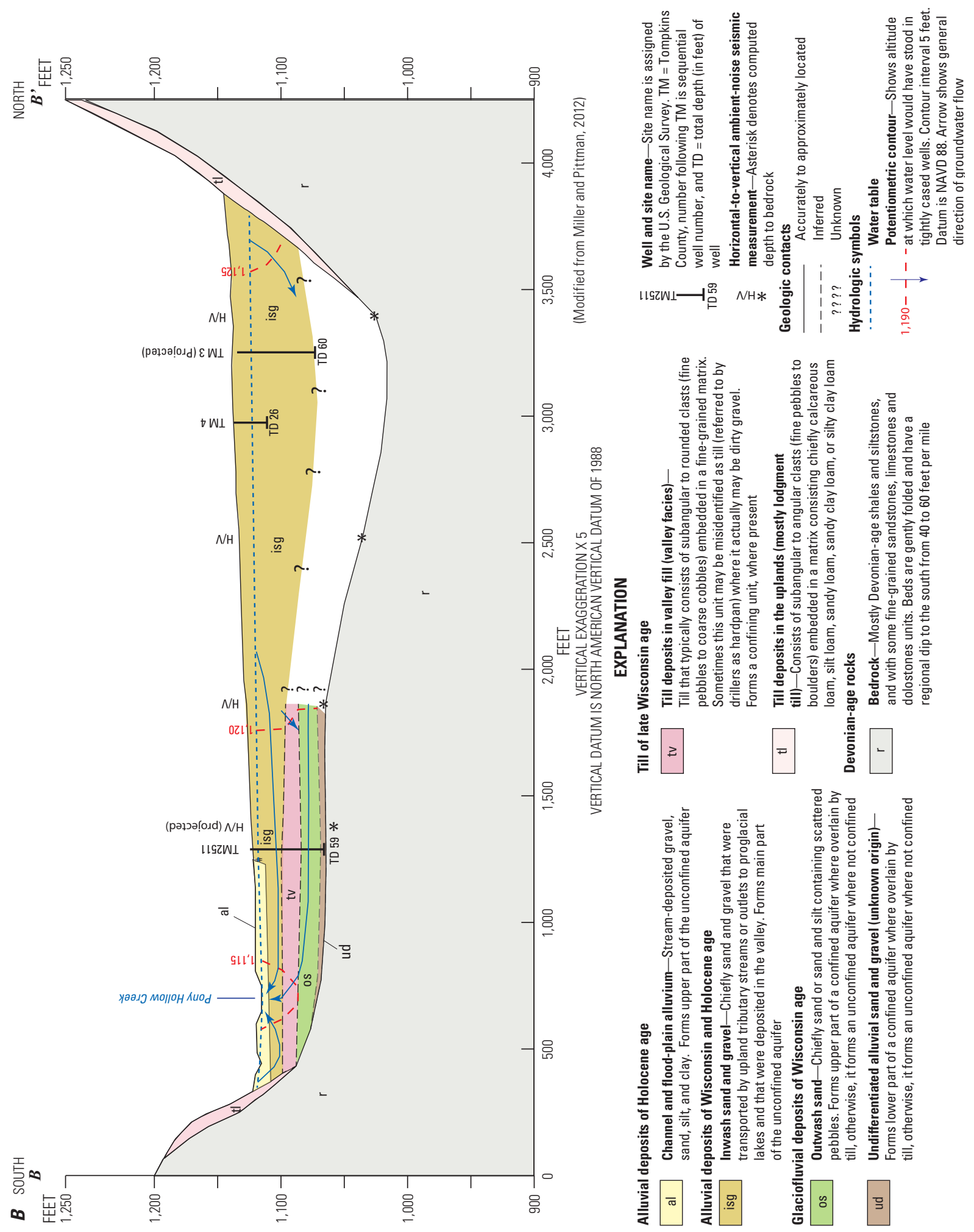

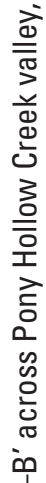
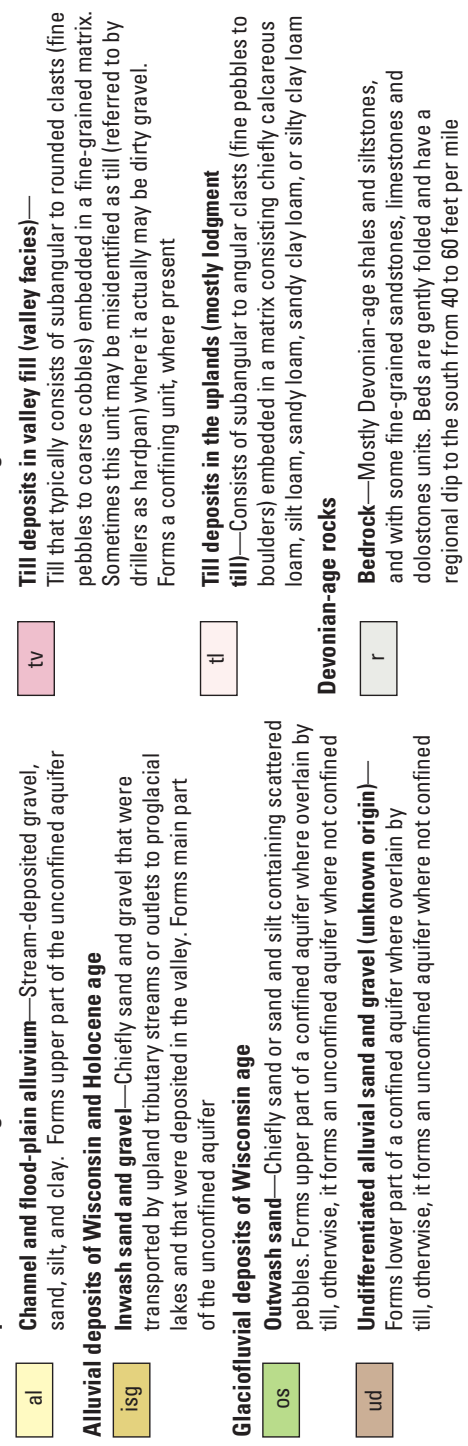

๑

๓ ธ

은

宆

우 드

亨

을 등

包

ปิ

응 유

음

六

तั

힝

ঠे ฮ

文

오 흔

충ㅎㅁ

응. ․ㅗㅇ

$\stackrel{Ð}{\ddagger}$

की

인 긍

近交

을

음 올

응 흥

흘음

ㅁำ

$<$

6 तั

흔 은 
floor, separating northward and southward major drainages (fig. 3). The divide defines the headwaters for water draining northward to Cayuga Lake (fig. 1) and then Lake Ontario (fig. 2), and that draining southward to Cayuta Creek and then to the Susquehanna River (not shown).

\section{Groundwater Levels and Flow}

In the Pony Hollow Creek valley, groundwater levels refer to the altitude of the water table (or hydraulic head) in the stratified-drift aquifer (fig. 6). Groundwater flows from high to low hydraulic head and perpendicular to the head gradient. A water-table map was constructed by using waterlevel measurements made in wells from the 1960s to 2011 (appendix 1), lidar data (where available) that were used to determine altitudes of perennial streams at $10-\mathrm{ft}$ intervals, and altitudes of large ponds and wetlands (fig. 7).

Groundwater flows perpendicular to the water-table contours in the stratified-drift aquifer in Pony Hollow Creek (fig.7). Flow is generally down valley and from the sides of the valley walls towards Pony Hollow Creek in most of the valley, at which point most groundwater discharges to the creek (Miller and Pitman, 2012). Where upland tributary streams lose water over the alluvial fans in the valleys, a localized groundwater mound forms beneath the streams and groundwater flow is radially away from the tributary channel and toward the main stream in the valley (Miller and Pitman, 2012) (fig. 7).

The water-table map in figure 7 was created by using groundwater-level measurements that were recorded at different times of the year from the 1960s to 2011 (Miller and Pitman, 2012). This approach was deemed reasonable because there were no measured long-term changes in water levels during this period (Miller and Pitman, 2012) and because the contour interval presented is large enough ( $20 \mathrm{ft}$ ) to take into account seasonal fluctuations in this area (which are normally less than $20 \mathrm{ft}$ ) without having the contours be inaccurate. There are no large public water-supply wells or commercial or industrial wells in the study area that would discharge large quantities of water from the aquifer and affect water levels. Additionally, the number of homeowner wells in the study area has remained relatively stable for the last 50 years, so no large changes in average water levels in the aquifer over that period would likely occur. In addition, the average annual fluctuation of the water table in the stratified-drift aquifers in the Pony Hollow Creek valley typically ranges from 5 to $10 \mathrm{ft}$, which is the same or smaller than the contour interval on the map (20 ft).

Annual water-table fluctuations (about $5 \mathrm{ft}$ ) are smaller near discharge areas, such as streams, and largest (about $10 \mathrm{ft}$ ) where greater amounts of recharge occur, such as along the valley walls and beneath alluvial fans (Miller and Pitman, 2012). In areas adjacent to gaining streams and large surface-water bodies such as lakes, ponds, and wetlands, the altitude of the water table reflects the water level of the surface-water body. Annual water-levels are normally affected by changes in the amounts of recharge, such as precipitation or snowmelt, but only locally change the relation of groundwater and surface-water levels in the study area (Miller and Pitman, 2012). Because there are no long-term water-level trends in the area and the annual fluctuation of groundwater levels is less than the contour interval (fig. 7), the water table map is a useful representation of long-term, average-annual groundwater levels and the general directions of groundwater flow (Miller and Pitman, 2012).

\section{Water Quality}

Water samples were collected to characterize the chemical quality of surface water at seasonal low flow or at average base flow when streamflow is mainly groundwater discharge and the quality of groundwater from wells in the study area. Field measurements were made for $\mathrm{pH}$, specific conductance, and water temperature for surface-water and groundwater samples using a YSI-6920 multi-parameter meter that was maintained and calibrated according to standard USGS protocol (U.S. Geological Survey, variously dated). The concentrations of 40 constituents in surface-water samples and 44 constituents in groundwater samples were measured, including major inorganic ions, nutrients, trace metals, and dissolved gases.

On December 13, 2011, surface-water samples were collected from four sites in the Town of Newfield, including (1) Carter Creek at State Route 13 near Cayuta (station ID-01515583), (2) Pony Hollow Creek at State Route 13 northeast of Cayuta (station ID-01515586), (3) Chaffee Creek at State Route 13 near Cayuta (station ID- 01515592), and (4) Pony Hollow Creek at Morrell Road at Cayuta (station ID- 01515615) (fig.8). All surface-water samples were collected by an equal-width-increment sampling method using a USGS DH-59 sampler with 1-liter Teflon bottles using standard USGS water-quality sampling methods and equipment (U.S. Geological Survey, variously dated). Standard USGS procedures also were used to clean sampling equipment. Final rinsing of equipment was with pesticidegrade water - a high purity water.

Groundwater samples were collected from six residential domestic wells (fig. 8) on December 14 and 15, 2011. Groundwater samples were collected from residential domestic wells at a place in the water-delivery system before any filtration, water softeners, or purifiers to capture the native groundwater. Water in the home was allowed to run to void the well of at least 3 casing volumes of water, and samples were collected using Teflon fittings, hoses, and bottles only when physical properties ( $\mathrm{pH}$, specific conductance, and temperature) had stabilized. As done for the surface-water 


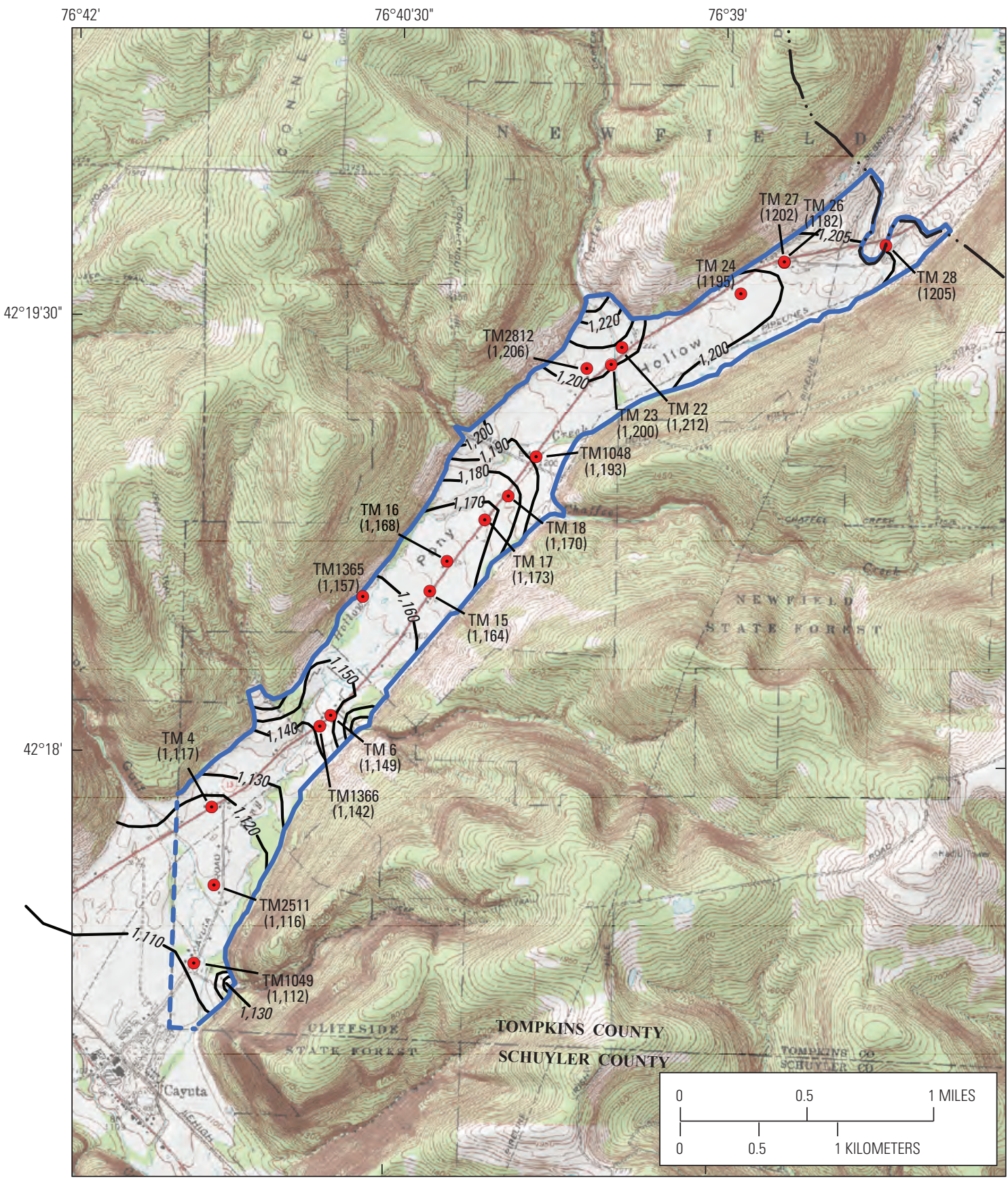

Base from U.S. Geological Survey, Seamless Data Distribution System, accessed

(Modififed from Miller and Pittman, 2012

(IT) projection,

Zone 18. Shading from 30-meter Digital Elevation Model accessed in 2009 at

http://nationalmap.gov/elevation.html\#data, UTM, Zone 18.

\section{EXPLANATION}

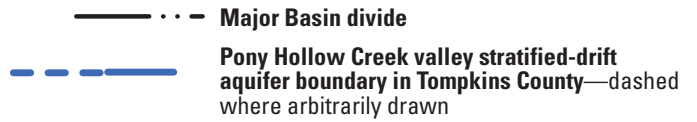

Well and site name-Site name is assigned by U. S. Geological Survey. $(1,120)-W e l l$ data are in Appendix 1. Number in parenthesis is water-level altitude. aquifer boundary in Tompkins County-dashed where arbitrarily drawn

-1,010 - Generalized water-table altitude - Shows approximate altitude of the water level in the unconfined aquifer in the Pony Hollow Creek valley derived from measurements made from historic groundwater-level data throughout several decades and during all seasons (1960s to 2011), and from approximate surface-water altitudes estimated from light detection and ranging (lidar) data, where available; and in areas where lidar data were unavailable, as indicated on 1:24,000-scale topographic maps; therefore, the contours are an approximation and reflect a generalized conception of the water table in this area. Contour interval 10 feet. Datum is North American Vertical Datum of 1988.

Figure 7. Water-level measurements and water-table surface contours in the Pony Hollow Creek valley Tompkins County, New York. (modified from Miller and Pitman, 2012). 


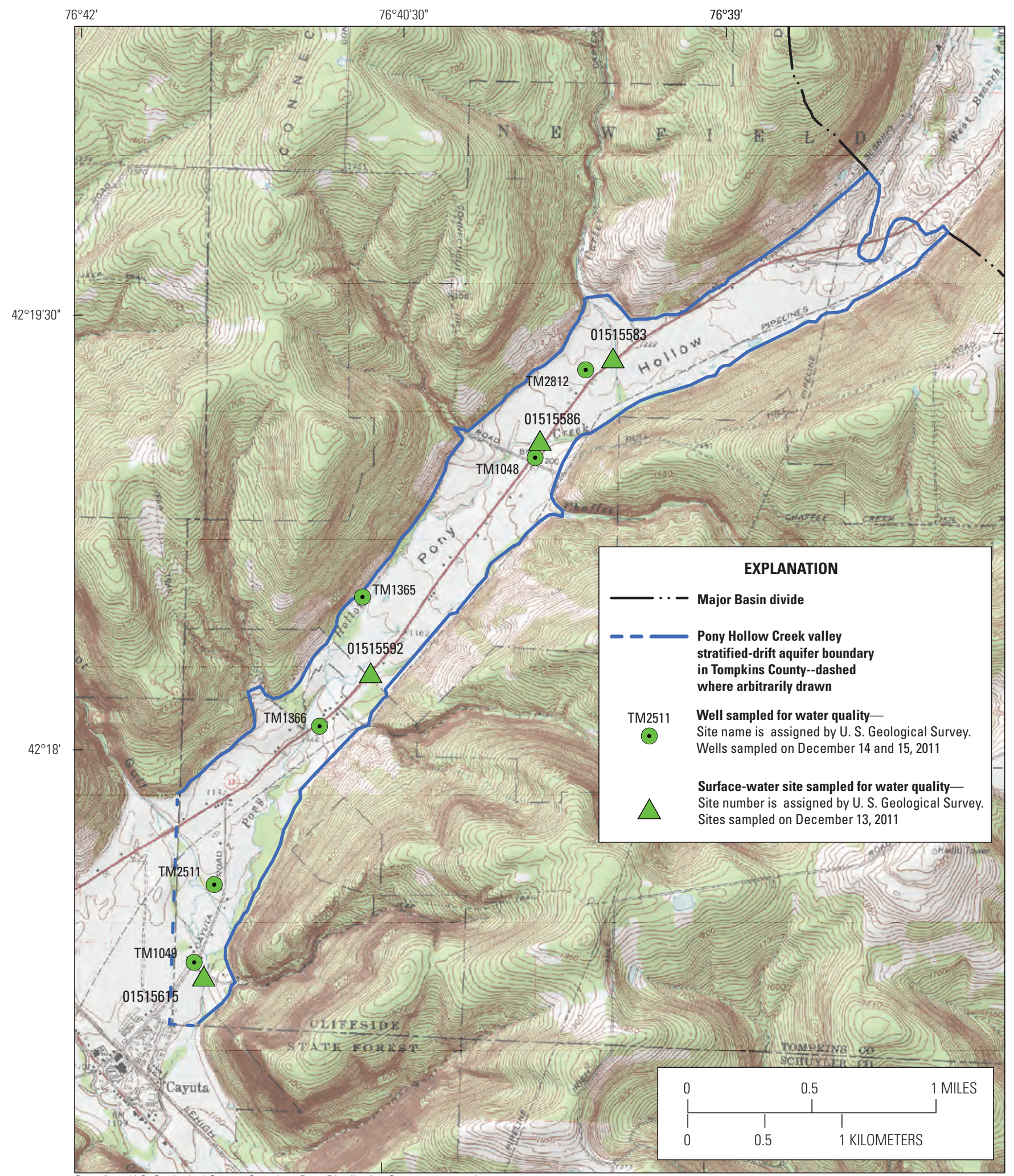

Base from U.S. Geological Survey, Seamless Data Distribution System, accessed in 2009 at http://seamless.usgs.gov, Universal Transverse Mercator (UTM) projection,

Zone 18. Shading from 30-meter Digital Elevation Model accessed in 2009 at

http://nationalmap.gov/elevation.html\#data, UTM, Zone 18.

Figure 8. Location of stream sites and wells sampled in the Pony Hollow Creek valley, Tompkins County, New York, December 13-15, 2011. 
equipment, standard cleaning procedures (U.S. Geological Survey, variously dated) were followed with rinsing by pesticide-grade water.

All samples were analyzed by the USGS National Water Quality Laboratory (NWQL) in Denver, Colorado. The NWQL participates satisfactorily in the USGS Standard Reference Water Sample Program and in a blind sample program. Analytical results for selected constituents are compared with Federal and State drinking-water standards. The standards include maximum contaminant levels (MCLs), secondary maximum contaminant levels (SMCLs), and health advisories (HAs) established by the U.S. Environmental Protection Agency (EPA; U.S. Environmental Protection Agency, 2006).

\section{Surface Water}

Four surface-water samples were collected by USGS personnel on December 13, 2011, during seasonal base-flow conditions. These surface-water samples were collected in December because of logistics and because winter samples can reflect base flow conditions provided snowmelt and surface-water contributions are at a minimum. If these conditions are met, winter base-flow conditions can be an approximation of the chemical quality of groundwater because streamflow during this time is composed largely of groundwater discharging into streams with little snowmelt or surface runoff. In addition, microbial activity, which can alter the concentrations of some constituents through contact with air and stream biota, is at a minimum in December. For example, microbial activity (associated with algal growth in the streams during warm seasons) can change dissolved oxygen concentrations or use the nitrogen in the water, potentially causing a decrease in nitrate concentrations (Miller and Pitman, 2012). However, the quality of surface water on December 13, 2011, may not reflect extreme base flow conditions because groundwater discharge to the streams likely was diluted by a small amount of surface runoff from snowmelt and local rainfall. Because air temperatures at the nearest weather station (Freeville $1 \mathrm{NE}$; National Weather Service station no. 303050) were in the lower 40-to upper 50 -degree range, and there was about 0.5 inch of rainfall in the area for the preceding week, it is probable that overland runoff into the streams somewhat diluted the groundwater discharge with surface water and snowmelt. Thus, the samples may not reflect only groundwater input to the streams. Field measurements of $\mathrm{pH}$, dissolved oxygen, specific conductance, and temperature, and the results of laboratory analyses are presented in table 1.

\section{Physiochemical Properties}

The $\mathrm{pH}$ of surface-water samples ranged from 7.5 to 7.7, with a median value of 7.6 (table 1); $\mathrm{pH}$ values for all
4 samples were within the accepted EPA SMCL range of 6.5 to 8.5 (U.S. Environmental Protection Agency, 2006). Specific conductance of the samples ranged from 62 to 152 microsiemens per centimeter at 25 degrees Celsius $\left(\mu \mathrm{S} / \mathrm{cm}\right.$ at $25^{\circ} \mathrm{C}$ ), with a median value of $105 \mu \mathrm{S} / \mathrm{cm}$.

\section{Common Inorganic Constituents}

The cation detected in the greatest concentration was calcium, which ranged from 6.76-18.8 milligrams per liter $(\mathrm{mg} / \mathrm{L})$, with a median value of $12.6 \mathrm{mg} / \mathrm{L}$ (table 1 ). Magnesium concentrations ranged from 2.26 to $4.49 \mathrm{mg} / \mathrm{L}$, with a median of $3.2 \mathrm{mg} / \mathrm{L}$. Calcium and magnesium contribute to water hardness, which ranged from 26.2 to $65.9 \mathrm{mg} / \mathrm{L}$ as calcium carbonate $\left(\mathrm{CaCO}_{3}\right)$, with a median of $45.3 \mathrm{mg} / \mathrm{L}$. Sodium concentrations ranged from 2.2 to $5.29 \mathrm{mg} / \mathrm{L}$, with a median value of $3.12 \mathrm{mg} / \mathrm{L}$. Potassium concentrations ranged from 0.52 to $0.803 \mathrm{mg} / \mathrm{L}$, with a median value of $0.652 \mathrm{mg} / \mathrm{L}$.

The anion detected in the greatest concentration was bicarbonate (Bicarbonate values were calculated from alkalinity concentrations, which are given in milligrams per liter of $\mathrm{CaCO}_{3}$ and are reported as calcium carbonate) - the concentrations ranged from 23.4 to $66.2 \mathrm{mg} / \mathrm{L}$, with a median value of $25.4 \mathrm{mg} / \mathrm{L}$ (table 1). Chloride concentrations ranged from 1.49 to $7.47 \mathrm{mg} / \mathrm{L}$, with a median value of $3.20 \mathrm{mg} / \mathrm{L}$. Sulfate concentrations ranged from 8.62 to $10.6 \mathrm{mg} / \mathrm{L}$, with a median value of $9.71 \mathrm{mg} / \mathrm{L}$. Silica concentrations ranged from 6.09 to $6.49 \mathrm{mg} / \mathrm{L}$, with a median value of $6.17 \mathrm{mg} / \mathrm{L}$. Fluoride concentrations were all below the detection limit of $0.04 \mathrm{mg} / \mathrm{L}$. None of the inorganic major constituents collected from surface-water sites in the study area exceeded any Federal or State water-quality standards (table 1).

\section{Nutrients}

Nitrate plus nitrite, hereafter referred to as nitrate $(\mathrm{N})$ was the predominant nitrogen species present in all nutrient samples of surface water, ranging from less than the detection limit of $0.04 \mathrm{mg} / \mathrm{L}$ to $0.656 \mathrm{mg} / \mathrm{L}$ as nitrogen (table 1).

Elevated concentrations of nitrogen can cause excessive plant and algal growth in streams, depleting oxygen and stressing organisms in their aquatic habitat - it also is a human health concern when the concentration is more than $10 \mathrm{mg} / \mathrm{L}$ (U.S. Environmental Protection Agency, 2006). However, the concentration of nitrate in the four surface-water samples is considered to be very low. Orthophosphate concentrations were detected at the reporting limit $(0.005 \mathrm{mg} / \mathrm{L}$ as phosphorus) in three of the surface-water samples, whereas results from the fourth sample indicated a concentration of $0.014 \mathrm{mg} / \mathrm{L}$. None of the surface-water samples exceeded Federal or State drinking-water standards for nitrate or nitrite (table 1). 
Table 1. Physical properties and concentrations of inorganic constituents, nutrients, and dissolved gases in surface-water samples in the Pony Hollow Creek valley, Tompkins County, New York, December 13, 2011.

[Sampling site location is shown in figure 8. USGS, U.S. Geological Survey; NWIS, National Water Information System; mg/L, milligrams per liter; $\mu$ S/cm, microsiemens per centimeter at 25 degrees Celsius; ${ }^{\circ} \mathrm{C}$, degrees Celsius; $\mathrm{CaCO}_{3}$, calcium carbonate; $\mathrm{N}$, nitorgen; $\mathrm{NO}_{2}$, nitrite; $\mathrm{NO}_{3}$, nitrate; $\mathrm{ft} / \mathrm{s}$, cubic feet per second; <, less than; --, not analyzed; XX, not available ]

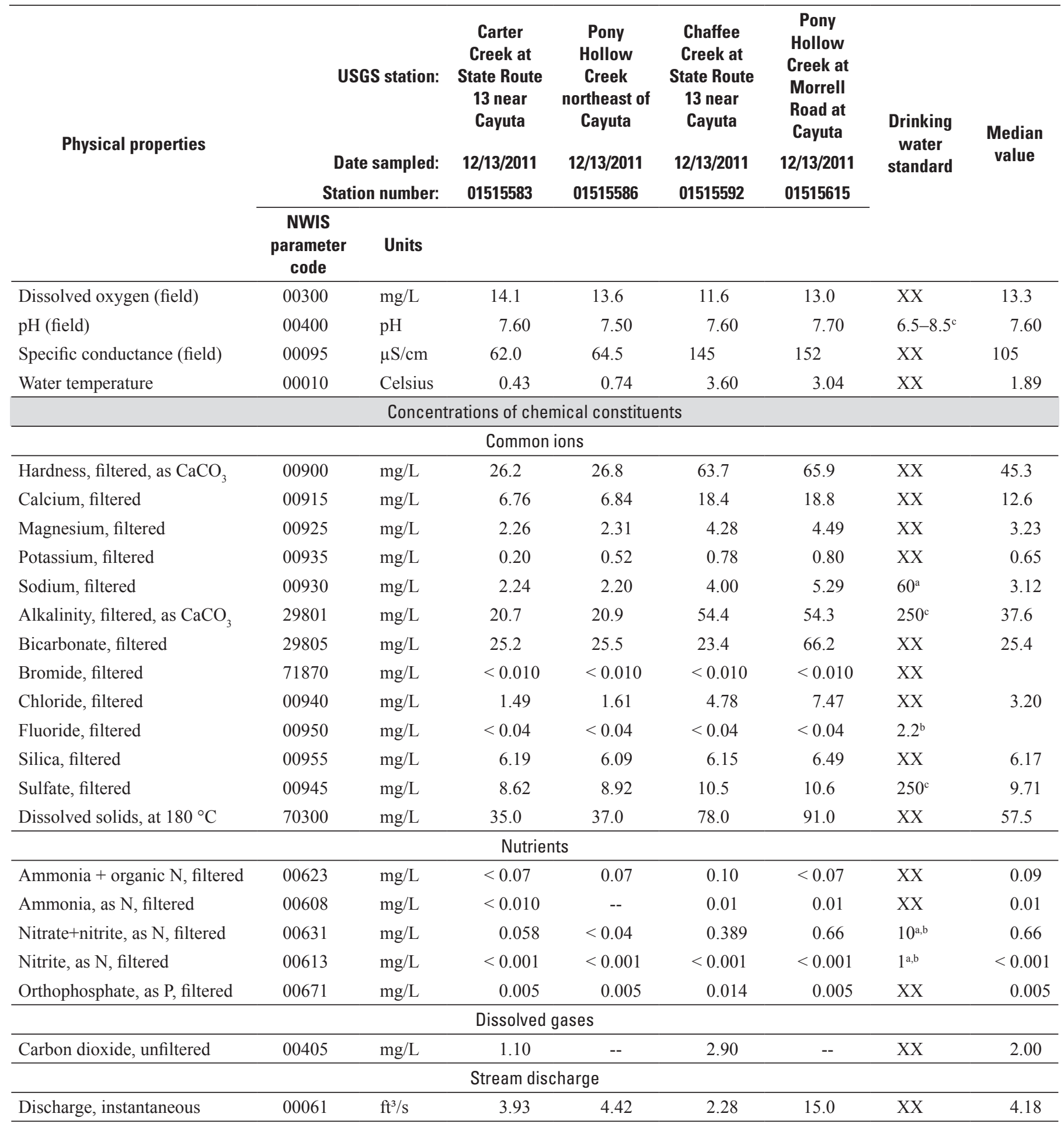

${ }^{a}$ U.S. Environmental Protection Agency (USEPA) drinking water advisory taste threshold.

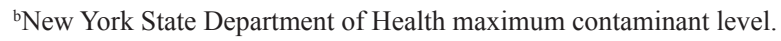

'USEPA secondary maximum contaminant level. 


\section{Trace Elements}

Trace elements detected in at least one surface-water sample included aluminum, antimony, arsenic, barium, boron, chromium, cobalt, iron, lead, lithium, manganese, molybdenum, nickel, strontium, uranium, and zinc (table 2). The trace elements detected in the greatest concentrations were aluminum, barium, boron, iron, lithium, manganese, and strontium. No samples exceeded Federal or State MCLs (table 2). Aluminum concentrations ranged from 6.35 to $9.48 \mu \mathrm{g} / \mathrm{L}$, with a median value of $7.3 \mu \mathrm{g} / \mathrm{L}$. Arsenic concentrations ranged from 0.128 to $0.180 \mu \mathrm{g} / \mathrm{L}$, with a median of $0.158 \mu \mathrm{g} / \mathrm{L}$ (table 2). Barium concentrations ranged from 15.4 to $34.7 \mu \mathrm{g} / \mathrm{L}$, with a median of $21.6 \mu \mathrm{g} / \mathrm{L}$. Boron concentrations ranged from 7 to $14 \mu \mathrm{g} / \mathrm{L}$, with a median of $8.89 \mu \mathrm{g} / \mathrm{L}$. An MCL has not yet been established for boron. Iron concentrations ranged from 6.88 to $30.7 \mu \mathrm{g} / \mathrm{L}$, with a median of $17.2 \mu \mathrm{g} / \mathrm{L}$. Lead was detected in all four surfacewater samples, ranging from 0.047 to $0.108 \mu \mathrm{g} / \mathrm{L}$, with a median value of $0.074 \mu \mathrm{g} / \mathrm{L}$, which is well below the EPA MCL of $15 \mu \mathrm{g} / \mathrm{L}$. Lithium concentrations ranged from 0.438 to $1.49 \mu \mathrm{g} / \mathrm{L}$, with a median of $0.895 \mu \mathrm{g} / \mathrm{L}$. An MCL has not yet been established for lithium. Strontium concentrations ranged from 26.9 to $46.4 \mu \mathrm{g} / \mathrm{L}$, with a median of $34.4 \mu \mathrm{g} / \mathrm{L}$. An MCL has not yet been established for strontium. Uranium concentrations ranged from 0.004 to $0.042 \mu \mathrm{g} / \mathrm{L}$, with a median of $0.021 \mu \mathrm{g} / \mathrm{L}$. No samples exceeded the EPA MCL of $30 \mu \mathrm{g} / \mathrm{L}$.

\section{Groundwater}

Groundwater samples were collected from six wells, all of which were completed in the unconfined sand and gravel aquifer in the Pony Hollow Creek valley (locations shown on fig. 8). All of these wells were drilled domestic wells that supplied private residences. Field measurements were made of $\mathrm{pH}$, specific conductance, dissolved oxygen, and water temperature. Samples were analyzed for inorganic major ions, nutrients, dissolved gases, and trace metals by the USGS NWQL in Denver, Colorado. Results of these chemical analyses are tabulated in tables 3 and 4 .

The wells that were sampled ranged from 26 to $59 \mathrm{ft}$ deep. The $\mathrm{pH}$ of the samples ranged from 7.1 to 8.2, with a median value of 7.8 (table 3 ); no $\mathrm{pH}$ measurement was outside the EPA SMCL range of 6.5 to 8.5 (table 3). Specific conductance values of the samples ranged from 185 to $339 \mu \mathrm{S} / \mathrm{cm}$ at $25^{\circ} \mathrm{C}$, with a median value of $275 \mu \mathrm{S} / \mathrm{cm}$.

\section{Inorganic Major lons}

Major ions in samples exceeded no Federal or State drinking-water health advisory standards (table 3 ). The cation that was detected in the greatest concentration was calcium, ranging from 28 to $46.4 \mathrm{mg} / \mathrm{L}$, with a median value of $43.5 \mathrm{mg} / \mathrm{L}$ (table 3). Magnesium concentrations ranged from
5.94 to $10.7 \mathrm{mg} / \mathrm{L}$, with a median value of $8.47 \mathrm{mg} / \mathrm{L}$. Calcium and magnesium contribute to water hardness as $\mathrm{CaCO}_{3}$, which ranged from 94.6 to $160 \mathrm{mg} / \mathrm{L}$, with a median value of $144 . \mathrm{mg} / \mathrm{L}$. Three of the six sampled wells yielded water with a hardness of $150 \mathrm{mg} / \mathrm{L}$ or greater, which is classified as "hard"; the hardness of the three remaining samples ranged from $94.6 \mathrm{mg} / \mathrm{L}$ (moderately hard) to $137 \mathrm{mg} / \mathrm{L}$ (hard) (Hem, 1985).

Sodium concentrations ranged from 2.35 to $9.34 \mathrm{mg} / \mathrm{L}$, with a median value of $4.71 \mathrm{mg} / \mathrm{L}$ (table 3 ) for the six wells sampled. The median concentration of $4.71 \mathrm{mg} / \mathrm{L}$ of sodium in these six residential domestic wells is lower than the median concentration of sodium of $12 \mathrm{mg} / \mathrm{L}$ detected in domestic wells completed in the glacial aquifers in the northern United States (Mullaney and others, 2009).

The anion detected in the greatest concentration was bicarbonate, ranging from 107 to $167 \mathrm{mg} / \mathrm{L}$, with a median value of $151 \mathrm{mg} / \mathrm{L}$ (table 3 ). Bicarbonate values were calculated from alkalinity concentrations, which are given in milligrams per liter of $\mathrm{CaCO}_{3}$ (calcium carbonate). Sulfate concentrations ranged from 8.41 to $18.8 \mathrm{mg} / \mathrm{L}$, with a median value of $12 \mathrm{mg} / \mathrm{L}$. Alkalinity, which results from dissolution of carbonate minerals such as those composing limestone and dolomite and is a measure of the capacity of water to neutralize acid, was measured by the USGS NWQL in Denver, Colorado using a fixed-endpoint titration method. Alkalinity concentrations ranged from 88 to $137 \mathrm{mg} / \mathrm{L}$ as $\mathrm{CaCO}_{3}$, with a median of $124 \mathrm{mg} / \mathrm{L}$. Alkalinity lower than $100 \mathrm{mg} / \mathrm{L}$ can be corrosive under low-pH conditions, and alkalinity greater than $150 \mathrm{mg} / \mathrm{L}$ can cause scale (lime) buildup in plumbing (Mechenich and Andrews, 2004). Chloride concentrations ranged from 2.69 to $21.5 \mathrm{mg} / \mathrm{L}$, with median value of $6.56 \mathrm{mg} / \mathrm{L}$ (table 3), which is substantially lower than the median concentration of $12 \mathrm{mg} / \mathrm{L}$ that was detected in domestic wells that tap the glacial aquifers in the northern United States (Mullaney and others, 2009).

Calcium with some sodium and magnesium generally dominate the cation composition; bicarbonate and, in a few samples, chloride dominate the anion composition in samples from this study area and in most samples from stratified-drift aquifers in Tompkins County. The water chemistry in the stratified-drift aquifers throughout Tompkins County is similar because the geologic settings of all the areas are similar.

\section{Nutrients}

Groundwater samples from each of the six residential domestic wells were analyzed for several nitrogen and phosphorus species (table 3 ). Nitrate was present in all six wells, and had concentrations ranging from 0.355 to $1.17 \mathrm{mg} / \mathrm{L}$, with a median value of $0.713 \mathrm{mg} / \mathrm{L}$. These nitrate concentrations are well below the EPA MCL of $10 \mathrm{mg} / \mathrm{L}$ (U.S. Environmental Protection Agency, 2006), and are considered low for unconfined sand and gravel aquifers which are typically affected by nitrate sources such as septic systems and fertilizer use. 
Table 2. Concentrations of trace metals in surface-water samples from the Pony Hollow Creek valley, Tompkins County, New York, December 13, 2011.

[Sampling site location is shown in figure 1. USGS, U.S. Geological Survey; NWIS, National Water Information System; $\mu \mathrm{g} / \mathrm{L}$, micrograms per liter; <, less than; XX, not available]

\begin{tabular}{|c|c|c|c|c|c|c|c|c|}
\hline \multirow[t]{2}{*}{ Trace metals } & $\begin{array}{r}\text { Dat } \\
\text { Stati }\end{array}$ & $\begin{array}{l}\text { sampled: } \\
\text { number: }\end{array}$ & $\begin{array}{c}\text { Carter } \\
\text { Creek at } \\
\text { State Route } \\
13 \text { near } \\
\text { Cayuta } \\
\text { 12/13/2011 } \\
01515583 \\
\end{array}$ & $\begin{array}{c}\begin{array}{c}\text { Pony } \\
\text { Hollow } \\
\text { Creek } \\
\text { northeast of } \\
\text { Cayuta }\end{array} \\
\text { 12/13/2011 } \\
01515586 \\
\end{array}$ & $\begin{array}{c}\text { Chaffee } \\
\text { Creek at } \\
\text { State Route } \\
13 \text { near } \\
\text { Cayuta } \\
12 / 13 / 2011 \\
01515592 \\
\end{array}$ & $\begin{array}{c}\text { Pony } \\
\text { Hollow } \\
\text { Creek at } \\
\text { Morrell } \\
\text { Road at } \\
\text { Cayuta } \\
\text { 12/13/2011 } \\
01515615 \\
\end{array}$ & \multirow[t]{2}{*}{$\begin{array}{c}\text { Drinking } \\
\text { water } \\
\text { standard }\end{array}$} & \multirow[t]{2}{*}{$\begin{array}{c}\text { Median } \\
\text { value }\end{array}$} \\
\hline & $\begin{array}{c}\text { NWIS } \\
\text { parameter } \\
\text { code }\end{array}$ & Units & \multicolumn{4}{|c|}{ Concentrations of chemical constituents } & & \\
\hline Aluminum, filtered & 01106 & $\mu \mathrm{g} / \mathrm{L}$ & 7.00 & 6.35 & 7.60 & 9.48 & $50 \mathrm{a}$ & 7.30 \\
\hline Antimony, filtered & 01095 & $\mu \mathrm{g} / \mathrm{L}$ & 0.029 & $<0.027$ & $<0.027$ & $<0.027$ & $6 b, c$ & 0.029 \\
\hline Boron, filtered & 01020 & $\mu \mathrm{g} / \mathrm{L}$ & 7.00 & 7.48 & 14.0 & 10.3 & $\mathrm{XX}$ & 8.89 \\
\hline Cadmium, filtered & 01025 & $\mu \mathrm{g} / \mathrm{L}$ & $<0.016$ & $<0.016$ & $<0.016$ & $<0.016$ & $5 \mathrm{~b}, \mathrm{c}$ & $<0.016$ \\
\hline Chromium, filtered & 01030 & $\mu \mathrm{g} / \mathrm{L}$ & 0.070 & 0.086 & 0.110 & 0.107 & $100 \mathrm{~b}, \mathrm{c}$ & 0.097 \\
\hline Cobalt, filtered & 01035 & $\mu \mathrm{g} / \mathrm{L}$ & 0.040 & 0.040 & 0.071 & 0.080 & $\mathrm{XX}$ & 0.056 \\
\hline Copper, filtered & 01040 & $\mu \mathrm{g} / \mathrm{L}$ & $<0.80$ & $<0.80$ & $<0.80$ & $<0.80$ & $1,000 \mathrm{a}$ & $<0.80$ \\
\hline Iron, filtered & 01046 & $\mu \mathrm{g} / \mathrm{L}$ & 10.6 & 6.88 & 23.8 & 30.7 & $300 a, b$ & 17.2 \\
\hline Lead, filtered & 01049 & $\mu \mathrm{g} / \mathrm{L}$ & 0.071 & 0.077 & 0.047 & 0.108 & $15 \mathrm{~d}$ & 0.074 \\
\hline Lithium, filtered & 01130 & $\mu \mathrm{g} / \mathrm{L}$ & 0.520 & 0.438 & 1.27 & 1.49 & $\mathrm{XX}$ & 0.895 \\
\hline Manganese, filtered & 01056 & $\mu \mathrm{g} / \mathrm{L}$ & 0.550 & 1.09 & 12.7 & 17.9 & $50 a-300 c$ & 6.90 \\
\hline Zinc, filtered & 01090 & $\mu \mathrm{g} / \mathrm{L}$ & $<1.40$ & $<1.40$ & 26.5 & 2.20 & $5,000 \mathrm{a}, \mathrm{c}$ & 14.4 \\
\hline
\end{tabular}

${ }^{a}$ U.S. Environmental Protection Agency (USEPA) secondary maximum contaminant level.

bUSEPA maximum contaminant level.

'New York State Department of Health (NYSDOH) maximum contaminant level.

dUSEPA drinking-water-regulation standard for lead revised in 2007. (http://water.epa.gov/drink/contaminants/basicinformation/lead.cfm)

eUSEPA proposed maximum contaminant level. 
Table 3. Physical properties and concentrations of inorganic constituents, nutrients, and dissolved gases in groundwater samples from unconsolidated aquifers in the Pony Hollow Creek valley, Tompkins County, New York, December 14-15, 2011.

[Sampling site location is shown in figure 1. USGS, U.S. Geological Survey; NWIS, National Water Information System; mg/L, milligrams per liter; $\mu \mathrm{S} / \mathrm{cm}$ at $25^{\circ} \mathrm{C}$, microsiemens per centimeter at 25 degrees Celsius; $<$, less than; XX, not available]

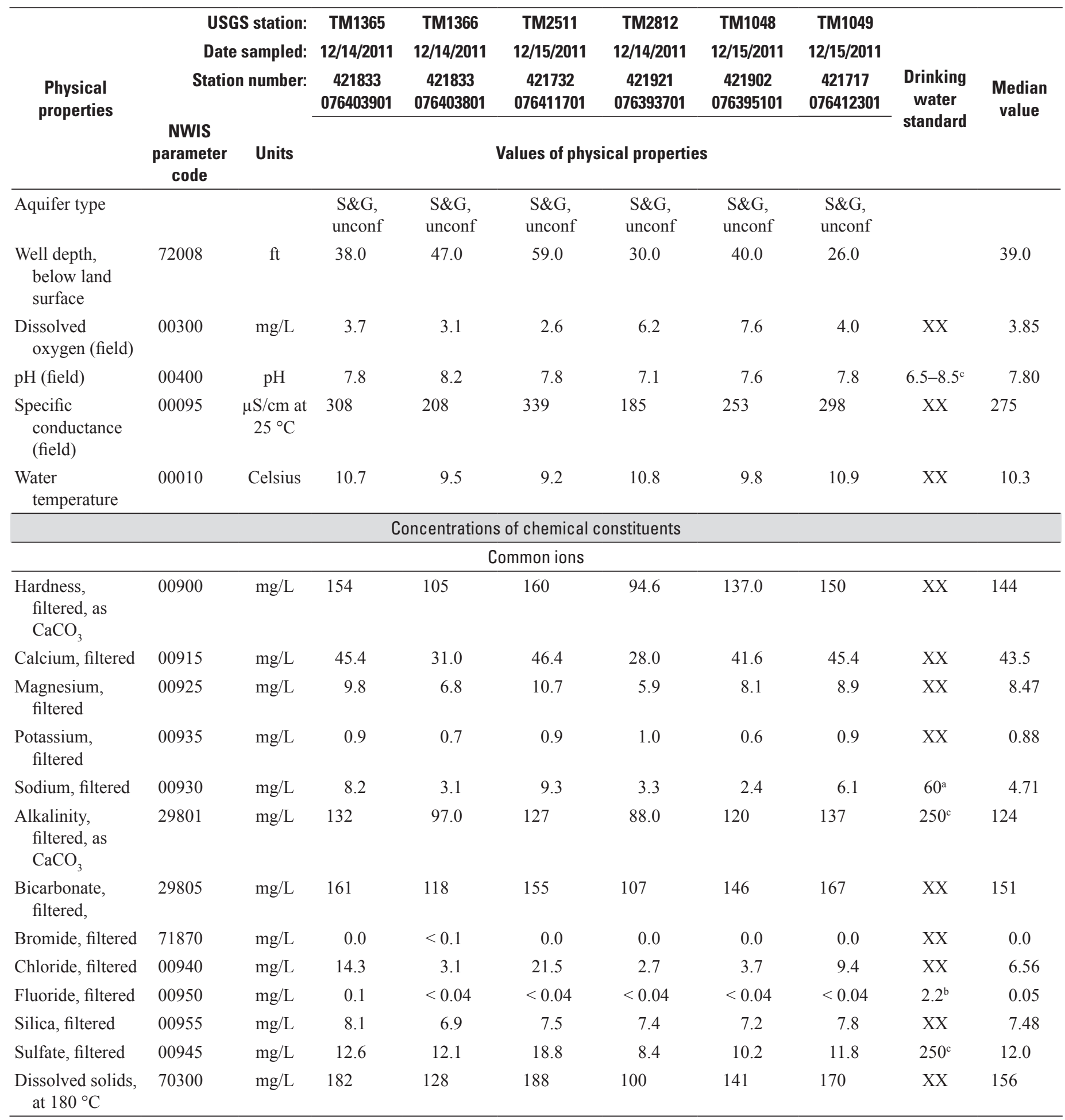


Table 3. Physical properties and concentrations of inorganic constituents, nutrients, and dissolved gases in groundwater samples from unconsolidated aquifers in the Pony Hollow Creek valley, Tompkins County, New York, December 14-15, 2011.—Continued

[Sampling site location is shown in figure 1. USGS, U.S. Geological Survey; NWIS, National Water Information System; mg/L, milligrams per liter; $\mu \mathrm{S} / \mathrm{cm}$ at $25^{\circ} \mathrm{C}$, microsiemens per centimeter at 25 degrees Celsius; $<$, less than; XX, not available]

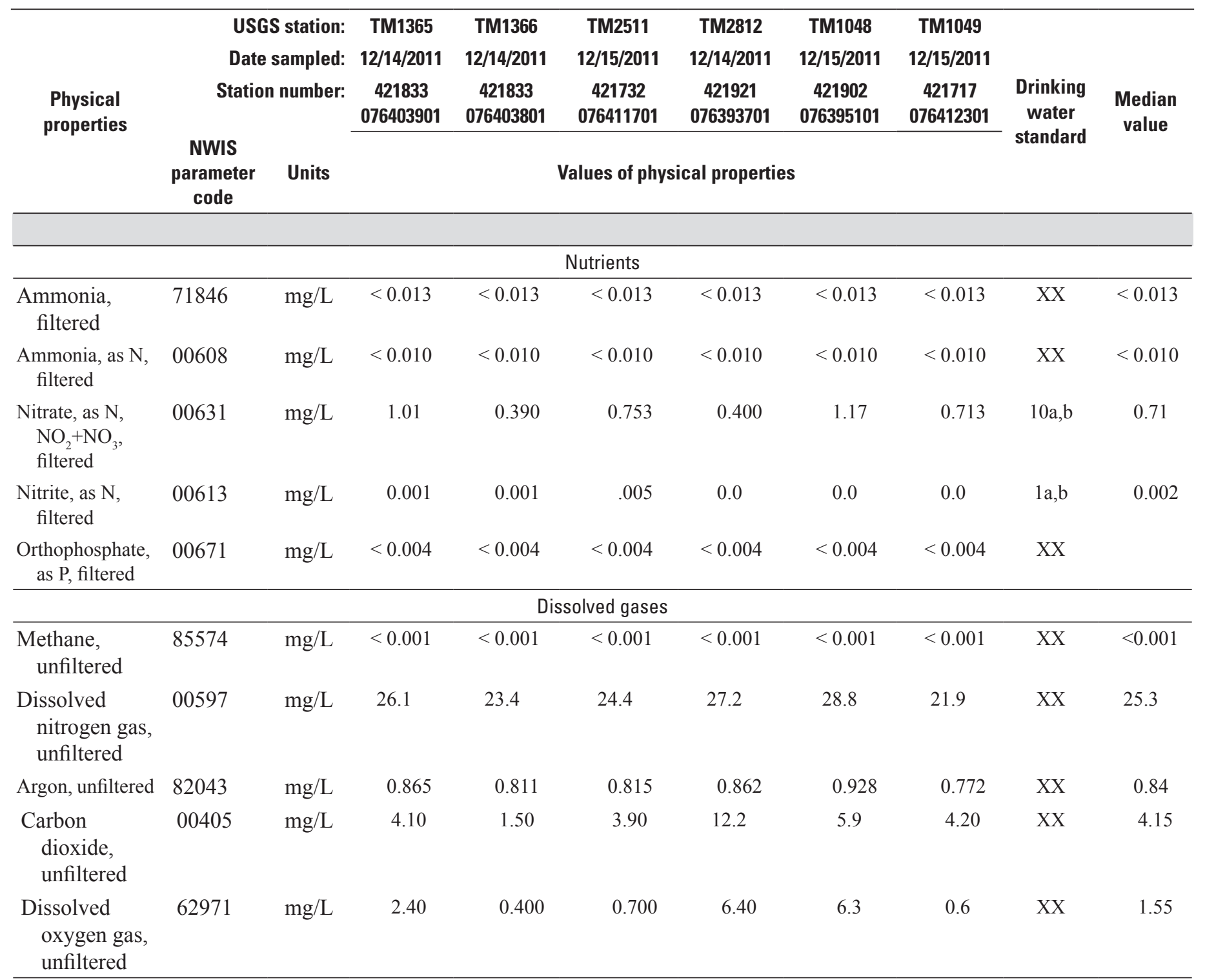

${ }^{a}$ U.S. Environmental Protection Agency (USEPA) drinking water advisory taste threshold.

${ }^{b}$ New York State Department of Health maximum contaminant level.

'USEPA secondary maximum contaminant level.

Nitrite was detected in all six wells, but at very small concentrations, ranging from 0.001 to $0.005 \mathrm{mg} / \mathrm{L}$, with a median value of $0.002 \mathrm{mg} / \mathrm{L}$. All results of nitrite analyses were below the EPA MCL of $1 \mathrm{mg} / \mathrm{L}$ (U.S. Environmental Protection Agency, 2006). Ammonia (filtered, as nitrogen) concentrations from all six wells were less than $0.013 \mathrm{mg} / \mathrm{L}$. Orthophosphate was not detected above the reporting limit of $0.004 \mathrm{mg} / \mathrm{L}$ in any of the six groundwater samples (table 3 ).

\section{Trace Elements}

Trace elements detected in every sample included aluminum, antimony, arsenic, barium, boron, chromium, cobalt, copper, iron, lithium, manganese, molybdenum, nickel, selenium, strontium, uranium, and zinc (table 4). The trace elements detected in the greatest concentrations were barium, boron, iron, lithium, manganese, and strontium. No 
Table 4. Concentrations of trace metals in groundwater samples from the the Pony Hollow Creek valley, Tompkins County, New York, December 14-15, 2011.

[Sampling site locations are shown in figure 1. USGS, U.S. Geological Survey; NWIS, National Water Information System; $\mu \mathrm{g} / \mathrm{L}$, micrograms per liter; $<$, less than; XX, not available]

\begin{tabular}{|c|c|c|c|c|c|c|c|c|c|c|}
\hline \multirow[t]{2}{*}{ Trace metals } & \multicolumn{2}{|c|}{$\begin{array}{l}\text { USGS station: } \\
\text { Date sampled: } \\
\text { Station number: }\end{array}$} & $\begin{array}{c}\text { TM1365 } \\
12 / 14 / 2011 \\
421833 \\
076403901 \\
\end{array}$ & $\begin{array}{c}\text { TM1366 } \\
12 / 14 / 2011 \\
421833 \\
076403801 \\
\end{array}$ & $\begin{array}{c}\text { TM2511 } \\
12 / 15 / 2011 \\
421732 \\
076411701 \\
\end{array}$ & $\begin{array}{c}\text { TM2812 } \\
12 / 14 / 2011 \\
421921 \\
076393701 \\
\end{array}$ & $\begin{array}{c}\text { TM1048 } \\
12 / 15 / 2011 \\
421902 \\
076395101 \\
\end{array}$ & $\begin{array}{c}\text { TM1049 } \\
\text { 12/15/2011 } \\
421717 \\
076412301 \\
\end{array}$ & \multirow{2}{*}{$\begin{array}{c}\text { Drinking } \\
\text { water } \\
\text { standard }\end{array}$} & \multirow[t]{2}{*}{$\begin{array}{c}\text { Median } \\
\text { value }\end{array}$} \\
\hline & $\begin{array}{c}\text { NWIS } \\
\text { parameter } \\
\text { code }\end{array}$ & Units & \multicolumn{6}{|c|}{ Concentrations of chemical constituents } & & \\
\hline Antimony, filtered & 01095 & $\mu \mathrm{g} / \mathrm{L}$ & $<0.027$ & $<0.027$ & 0.05 & $<0.027$ & $<0.027$ & $<0.027$ & $6^{\mathrm{b}, \mathrm{c}}$ & 0.05 \\
\hline Arsenic, filtered & 01000 & $\mu \mathrm{g} / \mathrm{L}$ & 0.20 & 0.17 & 0.36 & 0.05 & 0.10 & 0.17 & $10^{\mathrm{b}}$ & 0.17 \\
\hline Barium, filtered & 01005 & $\mu \mathrm{g} / \mathrm{L}$ & 41.2 & 37.4 & 77.4 & 24.6 & 23.4 & 46.6 & $2,000^{\mathrm{b}, \mathrm{c}}$ & 39.3 \\
\hline Beryllium, filtered & 01010 & $\mu \mathrm{g} / \mathrm{L}$ & $<0.006$ & $<0.006$ & $<0.006$ & $<0.006$ & $<0.006$ & $<0.006$ & $4^{\mathrm{b}, \mathrm{c}}$ & $<0.006$ \\
\hline Cobalt, filtered & 01035 & $\mu \mathrm{g} / \mathrm{L}$ & 0.04 & 0.03 & 0.06 & 0.25 & 0.04 & 0.10 & $\mathrm{XX}$ & 0.05 \\
\hline Copper, filtered & 01040 & $\mu \mathrm{g} / \mathrm{L}$ & 4.80 & 13.90 & 1.20 & $<0.80$ & 6.40 & $<0.80$ & $1,000^{\mathrm{a}}$ & 5.60 \\
\hline Iron, filtered & 01046 & $\mu \mathrm{g} / \mathrm{L}$ & $<3.2$ & $<3.2$ & $<3.2$ & 19.90 & $<3.2$ & $<3.2$ & $300^{\mathrm{a}, \mathrm{b}}$ & 19.9 \\
\hline Lead, filtered & 01049 & $\mu \mathrm{g} / \mathrm{L}$ & 0.17 & 0.15 & 0.09 & $<0.025$ & 2.39 & 0.03 & $15^{\mathrm{d}}$ & 0.15 \\
\hline Lithium, filtered & 01130 & $\mu \mathrm{g} / \mathrm{L}$ & 7.09 & 3.38 & 7.35 & 2.29 & 3.15 & 4.21 & $\mathrm{XX}$ & 3.80 \\
\hline Manganese, filtered & 01056 & $\mu \mathrm{g} / \mathrm{L}$ & 1.03 & 0.91 & 4.51 & 3.04 & 0.92 & 3.10 & $\begin{array}{l}50^{\mathrm{a}}- \\
300^{\mathrm{c}}\end{array}$ & 2.04 \\
\hline Molybdenum, filtered & 01060 & $\mu \mathrm{g} / \mathrm{L}$ & 0.13 & 0.04 & 0.17 & 0.02 & 0.02 & 0.05 & $\mathrm{XX}$ & 0.04 \\
\hline Nickel, filtered & 01065 & $\mu \mathrm{g} / \mathrm{L}$ & 0.33 & 0.22 & 0.39 & 0.24 & 0.38 & 0.36 & $X X$ & 0.35 \\
\hline
\end{tabular}

${ }^{a}$ U.S. Environmental Protection Agency (USEPA) secondary maximum contaminant level.

${ }^{b}$ USEPA maximum contaminant level.

'New York State Department of Health (NYSDOH) maximum contaminant level.

${ }^{d}$ USEPA drinking-water-regulation standard for lead revised in 2007. (http://water.epa.gov/drink/contaminants/basicinformation/lead.cfm)

eUSEPA proposed maximum contaminant level.

samples exceeded Federal or State MCLs. All aluminum concentrations, except one $(3.5 \mu \mathrm{g} / \mathrm{L})$, were less than $2.2 \mu \mathrm{g} / \mathrm{L}$. Arsenic concentrations ranged from 0.05 to $0.36 \mu \mathrm{g} / \mathrm{L}$, with a median value of $0.17 \mu \mathrm{g} / \mathrm{L}$ (table 4). All of the arsenic values are less than the EPA MCL for arsenic of $10 \mu \mathrm{g} / \mathrm{L}$. Barium concentrations ranged from 23.4 to $77.4 \mu \mathrm{g} / \mathrm{L}$, with a median of $39.3 \mu \mathrm{g} / \mathrm{L}$. Boron concentrations ranged from 10 to $14 \mu \mathrm{g} / \mathrm{L}$, with a median of $12 \mu \mathrm{g} / \mathrm{L}$; an MCL has not been established for boron. Iron concentrations in five of the wells were all less than the detection limit of $3.2 \mu \mathrm{g} / \mathrm{L}$; only data from one well (TM 2812) showed a measurable value of $19.9 \mu \mathrm{g} / \mathrm{L}$. Lead was detected in five out of six samples, ranging from $<0.025-2.39 \mu \mathrm{g} / \mathrm{L}$, but none exceeded the EPA MCL $(15 \mu \mathrm{g} / \mathrm{L})$. Lithium concentrations ranged from $2.29-7.35 \mu \mathrm{g} / \mathrm{L}$, with a median of $3.80 \mu \mathrm{g} / \mathrm{L}$; an MCL has not been established for lithium. Strontium concentrations ranged from $49.6-89.3 \mu \mathrm{g} / \mathrm{L}$, with a median of $72.3 \mu \mathrm{g} / \mathrm{L}$; an MCL has not been established for strontium. Uranium concentrations ranged from $0.042-0.264 \mu \mathrm{g} / \mathrm{L}$, with a median of $0.102 \mu \mathrm{g} / \mathrm{L}$; no samples exceeded the EPA MCL of $30 \mu \mathrm{g} / \mathrm{L}$. 


\section{Dissolved Gases}

A suite of dissolved gases, including methane, nitrogen, argon, carbon dioxide, and dissolved oxygen $\left(\mathrm{O}^{2}\right)$ were collected to determine the concentrations of these gases in groundwater. Methane concentrations were below the detection limit (table 3 ) and nitrogen was between 21 and $26 \mathrm{mg} / \mathrm{L}$. Dissolved oxygen concentrations were between 0.4 and $6.4 \mathrm{mg} / \mathrm{L}$. Dissolved oxygen concentrations, in concert with $\mathrm{NO}_{3}^{-}, \mathrm{MN}^{2+}, \mathrm{Fe}^{2+}$, and $\mathrm{SO}_{4}^{2-}$ concentrations, can suggest either reducing or oxidation conditions in groundwater-a concentration below $0.5 \mathrm{mg} / \mathrm{L}$ suggests reducing conditions normally found in confined aquifer systems (McMahon and others, 2009). All but one well had dissolved oxygen concentrations above $0.5 \mathrm{mg} / \mathrm{L}$ suggesting an unconfined aquifer. However, one well, TM1366, was less than $0.4 \mathrm{mg} / \mathrm{L}$ for dissolved oxygen concentration, but nevertheless, the sample was from the unconfined aquifer in the Pony Hollow Creek valley, as determined from well records and the immediate stratigraphy and water levels.

\section{Summary}

The Pony Hollow Creek valley aquifer was previously mapped in 2009 in cooperation with the New York State Department of Environmental Conservation. This project incorporates additional hydrogeologic information and waterquality data, collected from 2009 to 2011, that builds on the previously published report. Geologic materials in the study area include sedimentary bedrock, unstratified drift (till), stratified drift (glaciolacustrine and glaciofluvial deposits), and post-glacial alluvium. Stratified drift, consisting of sand and gravel, is the major component of the valley fill and forms an extensive unconfined aquifer in the study area. The unconfined aquifer is the source of water for most residents, farms, and businesses in the Pony Hollow Creek valley.

The water-table contours indicate that the general direction of groundwater flow within the Pony Hollow Creek valley stratified-drift aquifer is predominantly from the valley walls toward the main stream, where groundwater discharges from the aquifer system to the stream. Locally, where upland tributary streams lose water over the alluvial fans in the valley, a groundwater mound forms beneath the stream, and the direction of groundwater flow is radially away from the tributary channel.

On December 13, 2001, four surface-water samples were collected during average base flow conditions, including (1) Carter Creek at State Route 13 near Cayuta, (2) Pony Hollow Creek at State Route 13 northeast of Cayuta,

(3) Chaffee Creek at State Route 13 near Cayuta, and (4) Pony Hollow Creek at Merrell Road at Cayuta. During December 14 and 15, 2011, groundwater samples were collected from six residential domestic wells. Calcium dominates the cation composition and bicarbonate dominates the anion composition in the groundwater and surface-water samples, and none of the common inorganic constituents collected exceeded any Federal or State water-quality standards.

In surface-water samples, calcium and manganese concentrations ranged from 6.76 to 18.8 and 2.26 to 4.49 milligrams per liter $(\mathrm{mg} / \mathrm{L})$, respectively; concentrations of bicarbonate and chloride ranged from 23.4 to 66.2 and 1.49 to $7.47 \mathrm{mg} / \mathrm{L}$, respectively. Nitrate in surface-water samples ranged from less than the detection limit of 0.04 to $0.656 \mathrm{mg} / \mathrm{L}$ as nitrogen, and only one orthophosphate concentration $(0.014 \mathrm{mg} / \mathrm{L})$ was detected above the reporting limit $(0.005 \mathrm{mg} / \mathrm{L}$ as phosphorus). The trace elements detected in surface-water samples in the greatest concentrations were aluminum, barium, boron, iron, lithium, manganese, and strontium.

Concentrations of calcium and magnesium in groundwater samples ranged from 28 to 46.4 and 5.94 to $10.7 \mathrm{mg} / \mathrm{L}$, respectively; concentrations of bicarbonate and sulfate ranged from 107 to 167 and 8.41 to $18.8 \mathrm{mg} / \mathrm{L}$, respectively. Nitrate was present in all six sampled wells, and had concentrations ranging from 0.355 to $1.17 \mathrm{mg} / \mathrm{L}$. Orthophosphate was not detected above the reporting limit of $0.004 \mathrm{mg} / \mathrm{L}$ in any of the six groundwater samples. Trace elements detected in every sample included aluminum, antimony, arsenic, barium, boron, chromium, cobalt, copper, iron, lithium, manganese, molybdenum, nickel, selenium, strontium, uranium, and zinc. None of the analytes exceeded any State of Federal drinking-water standards

\section{References Cited}

Fountain, J.C., and Jacobi, R.D., 2000, Detection of buried faults and fractures using soil gas analysis: Environmental and Engineering Geosciences v. 6, p. 201-208.

Fullerton, D.S., 1980, Preliminary correlation of post-Erie interstadial events $(16,000-10,000$ radiocarbon years before present) central and eastern Great Lakes region, and Hudson, Champlain, and St. Lawrence lowlands, United States and Canada: U.S. Geological Survey Professional Paper 1089, $52 \mathrm{p}$.

Hem, J.D., 1985, Study and interpretation of the chemical characteristics of natural water (3d ed.): U.S. Geological Survey Water Supply Paper 2254, 264 p. (Also available at http://pubs.usgs.gov/wsp/wsp 2254/.)

McMahon, P.B., Cowdery, T.K., Chapelle, F.H., Jurgens, B.C., 2009, Redox Conditions in Selected Principal Aquifers of the United States: U.S. Geological Survey Fact Sheet 2009-3041, 6p. 
Mechenich, Christine, and Andrews, Elaine, 2004, Home water safety-Interpreting drinking-water results:

University of Wisconsin-Extension, Cooperative Extension Bulletin G3558-4, 12 p.

Miller, T.S., and Karig, D.E., 2010, Geohydrology of the stratified-drift aquifer system in the lower Sixmile Creek and Willseyville Creek trough, Tompkins County, New York: U.S. Geological Survey Scientific Investigations Report 2010-5230, 54 p.

Miller, T.S., and Pitman, L.J., 2012, Hydrogeology of the stratified-drift aquifers in the Cayuta Creek and Catatonk Creek valleys in parts of Tompkins, Schuyler, Chemung, and Tioga Counties, New York: U.S. Geological Survey Scientific Investigations Report 2012-5127, 44 p. 3 pls.

Mullaney, J.R., Lorenz, D.L., and Arntson, A.D., 2009, Chloride in groundwater and surface water in areas underlain by the glacial aquifer system, northern United States: U.S. Geological Survey Scientific Investigations Report 2009-5086, 41 p.
Podwysocki, M.H., Pohn, H.A., Phillips, J.D., Krohn, M.D., Purdy, T.L., and Merin, I.S., 1982, Evaluation of remote sensing, geological, and geophysical data for south-central New York and Northern Pennsylvania: U.S. Geological Survey Open-File Report 82-319, 179 p.

Rickard, L.V., and Fisher, D.W., 1970, Geologic map of New York, Finger Lakes Sheet: New York State Museum and Science Service, Map and Chart Series No. 15, 1:250,000.

U.S. Department of Agriculture, 2008, SSURGO digital soil-survey data, accessed October 30, 2008, at http:// soildatamart.nrcs.usda.gov.

U.S. Environmental Protection Agency, 2006, Drinking water standards and health advisories: Environmental Protection Agency EPA 822-R-06-013, August, 12 p.

U.S. Geological Survey, variously dated, National field manual for the collection of water-quality data: U.S. Geological Survey Techniques of Water-Resources Investigations, book 9, chaps. A1-A9, accessed September 20, 2009, available online at http://pubs.water.usgs.gov/twri9A. 


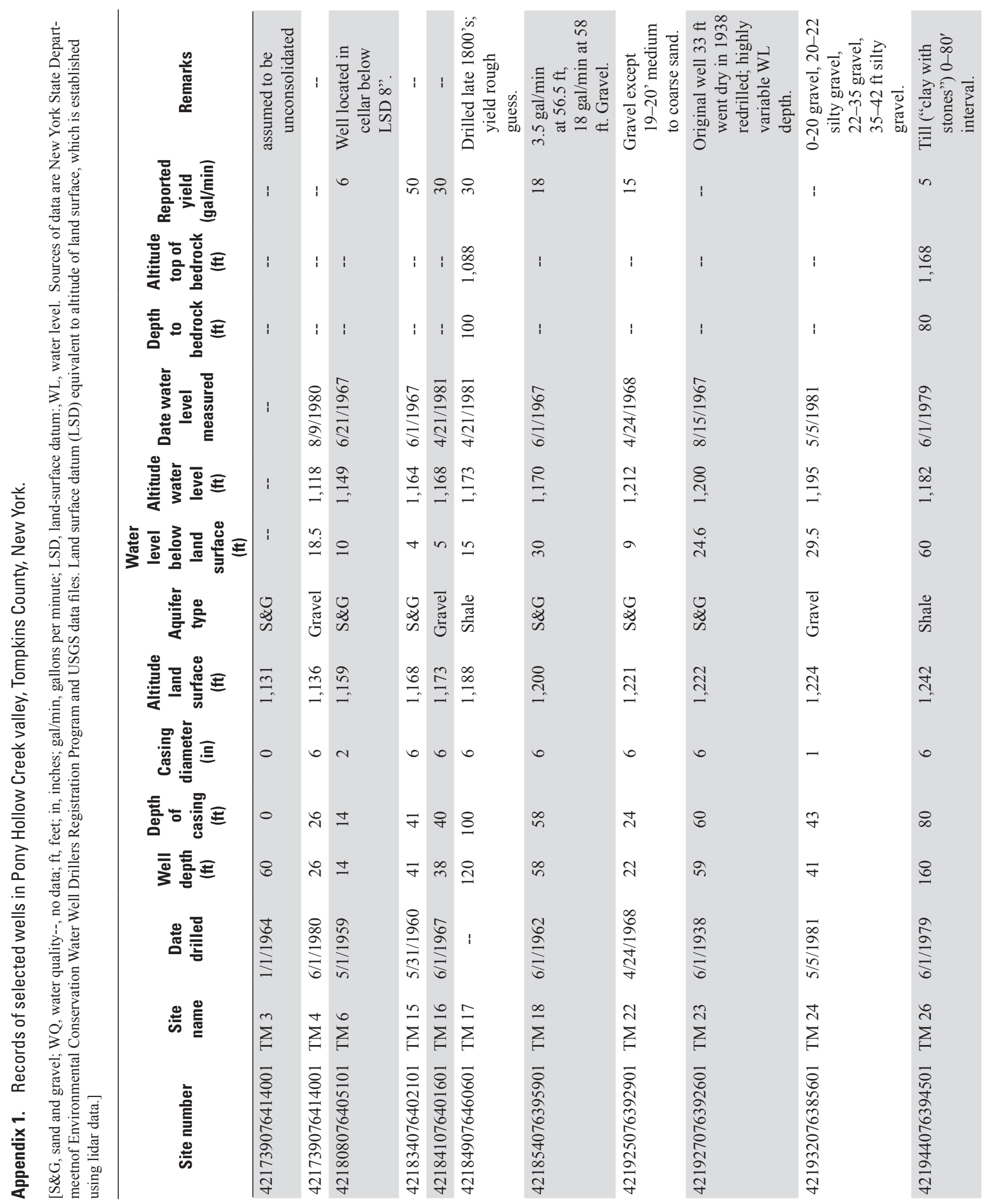




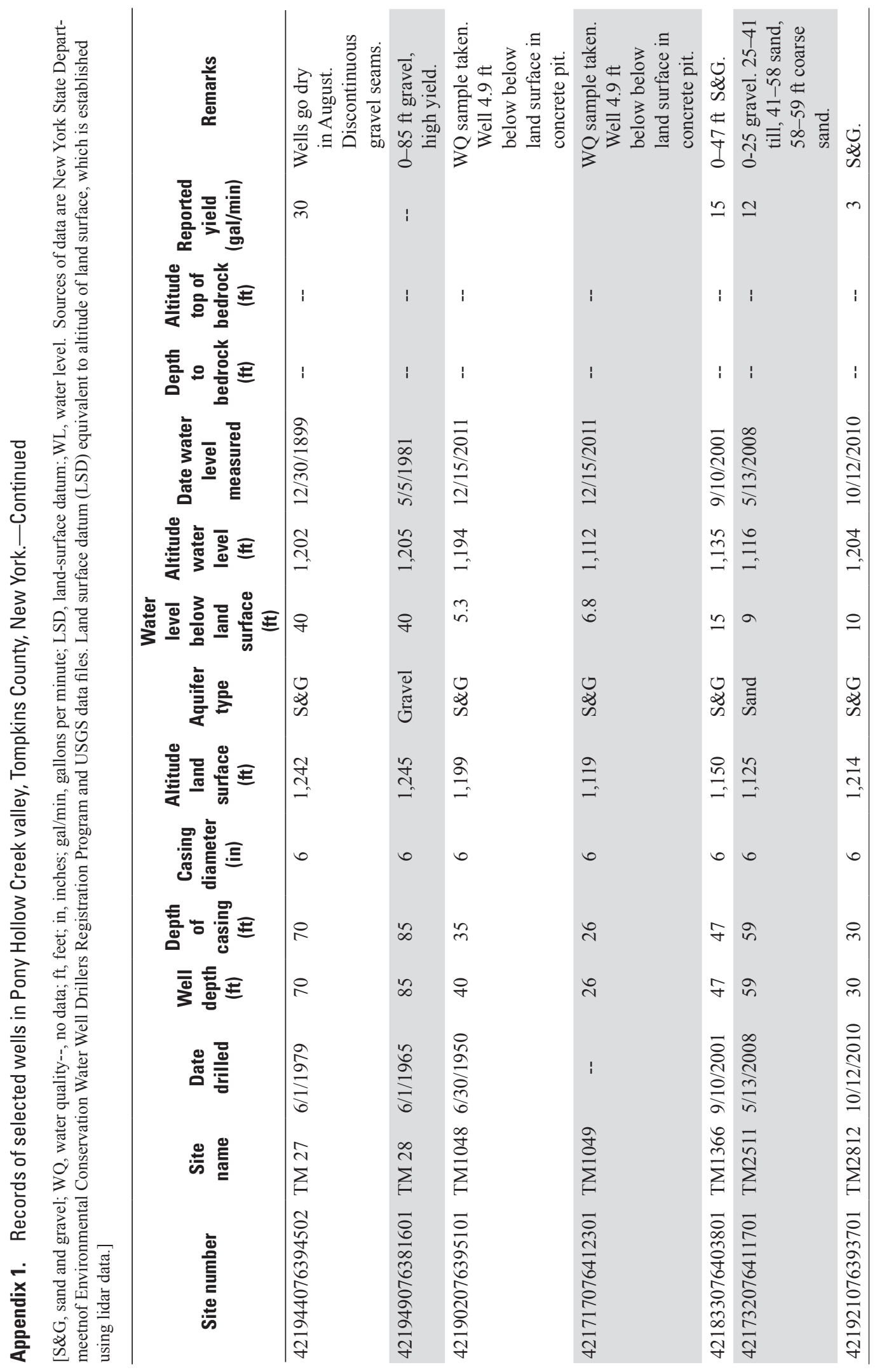



Prepared by the Pembroke Publishing Service Center

For additional information write to:

New York Water Science Center

U.S. Geological Survey

30 Brown Rd.

Ithaca, NY 14850

Information requests:

(518) 285-5602

or visit our Web site at: http://ny.water.usgs.gov 
